\title{
SAMe, Choline, and Valproic Acid as Possible Epigenetic Drugs: Their Effects in Pregnancy with a Special Emphasis on Animal Studies
}

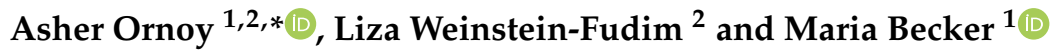 \\ 1 Adelson School of Medicine, Ariel University, Ariel 40700, Israel; mariabe@ariel.ac.il \\ 2 Department of Medical Neurobiology, Hebrew University Hadassah Medical School, \\ Jerusalem 9112102, Israel; liza.weinstein-f@mail.huji.ac.il \\ * Correspondence: ashero@ariel.ac.il or ornoy@cc.huji.ac.il; Tel.: +972-2-6758-329 or +972-50-6420030
}

check for updates

Citation: Ornoy, A.;

Weinstein-Fudim, L.; Becker, M. SAMe, Choline, and Valproic Acid as Possible Epigenetic Drugs: Their Effects in Pregnancy with a Special Emphasis on Animal Studies. Pharmaceuticals 2022, 15, 192. https://doi.org/ $10.3390 /$ ph15020192

Academic Editor: Marcin Ratajewski

Received: 28 December 2021

Accepted: 28 January 2022

Published: 3 February 2022

Publisher's Note: MDPI stays neutral with regard to jurisdictional claims in published maps and institutional affiliations.

Copyright: (C) 2022 by the authors. Licensee MDPI, Basel, Switzerland. This article is an open access article distributed under the terms and conditions of the Creative Commons Attribution (CC BY) license (https:// creativecommons.org/licenses/by/ $4.0 /)$.

\begin{abstract}
In this review, we discuss the functions and main effects on pregnancy outcomes of three agents that have the ability to induce epigenetic modifications: valproic acid (VPA), a well-known teratogen that is a histone deacetylase inhibitor; S-adenosylmethionine (SAMe), the most effective methyl donor; and choline, an important micronutrient involved in the one methyl group cycle and in the synthesis of SAMe. Our aim was to describe the possible effects of these compounds when administered during pregnancy on the developing embryo and fetus or, if administered postnatally, their effects on the developing child. These substances are able to modify gene expression and possibly alleviate neurobehavioral changes in disturbances that have epigenetic origins, such as autism spectrum disorder (ASD), depression, Rett syndrome, and fetal alcohol spectrum disorder (FASD). Valproic acid and SAMe are antagonistic epigenetic modulators whether administered in utero or postnatally. However, VPA is a major human teratogen and, whenever possible, should not be used by pregnant women. Most currently relevant data come from experimental animal studies that aimed to explore the possibility of using these substances as epigenetic modifiers and possible therapeutic agents. In experimental animals, each of these substances was able to alleviate the severity of several well-known diseases by inducing changes in the expression of affected genes or by other yet unknown mechanisms. We believe that additional studies are needed to further explore the possibility of using these substances, and similar compounds, for the treatment of "epigenetic human diseases".
\end{abstract}

Keywords: S-adenosylmethionine (SAMe); valproic acid (VPA); choline; epigenetic modulators; gene expression; gestation; epigenetic diseases

\section{Introduction}

With the advancement of our understanding of epigenetic mechanisms, increasingly more congenital malformations and human diseases are considered to have an epigenetic etiology [1-3]. Many of them affect the central nervous system and are among the leading psychiatric diseases, including depression, schizophrenia, and autism spectrum disorder $[1,2,4]$. Some teratogens (i.e., valproic acid) also exert damaging effects via epigenetic mechanisms [3,5]. These teratogens primarily affect the nervous system.

Long-term epigenetic changes are generally induced during developmental phases when epigenetic reprogramming occurs. The major round of epigenetic reprogramming takes place during embryonic development soon after fertilization, when most modified cytosines $(5 \mathrm{mC})$ are erased and de novo methylation events occur during the prenatal stage, forming the "future" epigenetic settings [6,7]. In humans, organ-specific DNA methylation patterns are highly dynamic between weeks 9 and 22 of gestation [8], during which different immature organ systems are sensitive to functional defects and malformations. 
Additionally, a large fraction of tissue-specific methylation patterns is laid down during the early postnatal period $[9,10]$.

Many environmental agents that are able to interfere with normal embryonic and fetal development exert their teratogenic and embryotoxic effects by inducing epigenetic changes, interfering with gene expression, and therefore inducing typical functional and morphological deviations. For example, VPA and alcohol are both well-known neuroteratogens but can also induce a variety of congenital malformations [5,11]. These epigenetic modifiers may affect humans and various animals.

The brain seems to respond differently from many organs to epigenetic changes [1,12] possibly because major developmental events in the brain occur at different times during prenatal and early postnatal development. This long developmental period seems to widen the temporal window of vulnerability and the number of developmental processes that may be affected by epigenetic changes $[9,13,14]$.

Many attempts to prevent some of these epigenetic modifications have been carried out, mainly in experimental animals. Attempts to prevent the damage using more physiologic "antagonistic" epigenetic modifiers have offered some success. For example, the treatment of pregnant mice exposed to large doses of alcohol with the methyl donor choline helped to alleviate the signs and symptoms induced by prenatal alcohol [15]. This led to some clinical trials with minimal success [16]. VPA-induced autistic-like behavior in mice was prevented by concomitant administration of S-adenosyl methionine $[17,18]$.

In this review, we will therefore discuss the epigenetic effects of three substances: VPA, which is a teratogen that induces histone deacetylase inhibition, thus affecting gene expression; SAMe, which is the physiologically most important methyl donor of living organisms; and choline, which is also involved in DNA methylation. Choline and SAMe are directly involved in one carbon metabolism while VPA is involved indirectly via its effects on histones. See Figure 1 for details of the one carbon cycle.

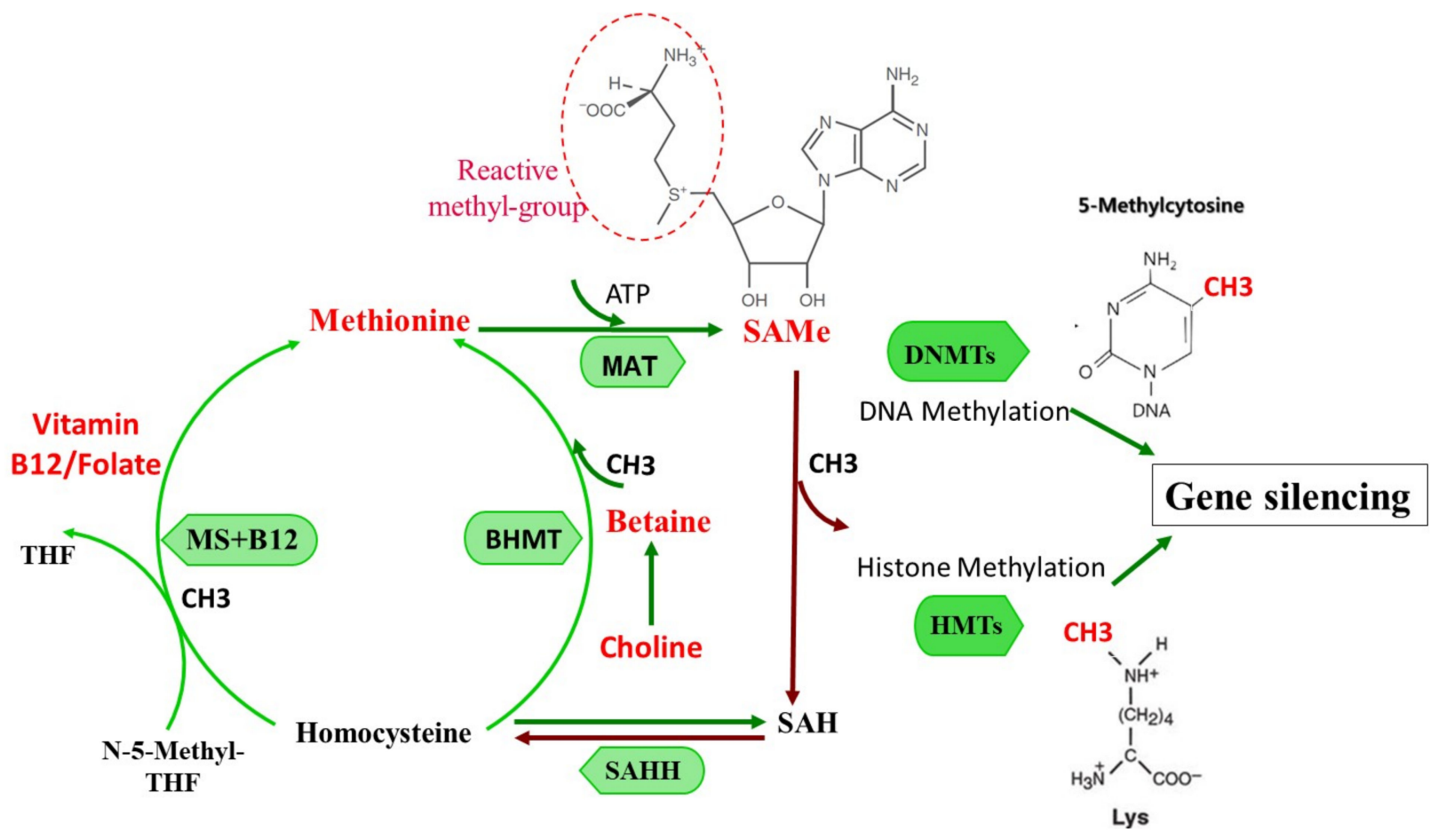

Figure 1. One-carbon metabolism and SAMe formation and function: Pathways of methionine, choline, and vitamin B6, B12-folate metabolism in the transmethylation cycle.

We will discuss their effects during pregnancy on the developing embryo and fetus and specifically report on the studies related to their use as epigenetic modifiers that may ameliorate damage induced by "epigenetic" teratogens. 
Methionine is catalyzed by methionine adenosyltransferase (MAT) to generate Sadenosylmethionine (SAMe). SAMe donates active methyl groups to the acceptor and is converted to S-adenosylhomocysteine (SAH). SAH hydrolase (SAHH) then catalyzes the reversible hydrolysis of SAH to form homocysteine. Two pathways metabolize homocysteine to resynthesize methionine from homocysteine. In the vitamin B12/folate pathway, the reaction is catalyzed by methionine synthase (MS), which requires normal concentrations of N-5-Methyl tetrahydrofolate (N-5-Methyl-THF) and vitamin B-12. A second pathway is catalyzed by betaine-homocysteine methyltransferase (BHMT), which requires betaine, a metabolite of choline.

SAMe donates the methyl group to DNA methyltransferases (DNMTS) or histone methyltransferases (HMTs), contributing to increased genomic methylome, and to gene silencing.

\section{Valproic Acid (VPA)}

VPA has been available on the market as an anticonvulsant since 1974, and is widely used because of its efficiency against several types of epilepsy and as a mood stabilizer for the treatment of bipolar disorder and against migraine. In the last few years, it has also been used in clinical trials to treat several types of malignancies, especially advanced prostatic carcinoma [19]. Due to its known teratogenic effects, it is generally contraindicated in pregnancy unless strictly needed [5].

The use of VPA during pregnancy in humans is associated with a 1-2\% incidence of neural tube defects, being associated mainly with lumbosacral meningomyelocele (spina bifida aperta) $[5,20]$. Other congenital malformations associated with exposure to valproic acid include facial clefts, and cardiovascular, genital (i.e., hypospadias), and limb abnormalities [21]. VPA, when added to other anticonvulsants, markedly increases the rate of malformations otherwise observed by the other drug alone. In addition, a specific "fetal valproate syndrome" has also been reported in several epidemiologic studies [5,22]. Infants with "fetal valproate syndrome" (VPA embryopathy) are prone to a variety of neurodevelopmental problems, including autism spectrum disorder (ASD). These data are based on prospective and retrospective studies of thousands of children born to VPA-treated mothers.

There seems to be a threshold regarding the teratogenic effects of VPA, ranging between daily doses of 600 and $1000 \mathrm{mg} /$ day [5].

\subsection{VPA and Autism Spectrum Disorder (ASD)}

A possible association between in utero VPA exposure and ASD was described by several investigators about 30 years ago. These children often also had the typical facial features of VPA embryopathy [23]. Many reports appeared thereafter in the literature associating VPA exposure with ASD. The rate of ASD among the offspring of women treated with VPA during pregnancy was found to be 3-5 times higher compared to the general population in a large epidemiologic study [24].

Various animal studies were carried out in order to mimic the effects of VPA on the human embryo and elucidate the mechanism/s of its teratogenic action. In most animals, the drug was teratogenic, but the effective teratogenic doses differed widely. VPA induces malformations of multiple organs in rodents that resemble those described in humans, including various neurobehavioral deficits resembling ASD in mice and in rats [25,26]. Rodier et al. found [27] that the injection of $350 \mathrm{mg}^{-1} \mathrm{~kg}^{-1}$ body weight to rats during days 11.5-12.5 of pregnancy reduced the number of neurons in motor cranial nerve nuclei and the size of the cerebellar hemispheres and also reduced the number of cerebellar Purkinje cells. It also caused a variety of behavioral changes mimicking ASD in human [28]. Similar changes were also observed in mice. Indeed, VPA-induced ASD-like behavior in rodents is a very popular model used to study the different aspects of human ASD [5,16,17].

The proposed mechanisms of VPA's action on the brain include increased glutamatergic neural density, which leads to an excitatory/inhibitory imbalance, altered monoamines 
brain turnover, and increased reactive oxygen species [17,29]. The most important proposed mechanism is the induction of epigenetic changes due to the known VPA inhibition of histone deacetylase, possibly affecting DNA methylation $[17,18,30]$.

Further support for an epigenetic mechanism can be found by the fact that ASD-like behavioral changes were transmitted for 3 generations in the offspring of mice treated on day 12 of gestation with a single dose of VPA [31].

\subsection{Inhibition of Histone Deacetylases (HDACs) by VPA: The Effects on the Epigenome}

The most popular proposed mechanism of VPA teratogenicity involves a combination of possible changes in gene expression resulting from histone deacetylase inhibition induced by VPA in the embryo [32-37].

DNA is wrapped around the histone protein octamer, which contains two copies of histone molecules (H2A, H2B, H3, and H4) [38]. This complex nucleosome is the basic unit of chromatin. The main function of histones is the packaging of genomic DNA inside the nucleus. Nucleosomes are connected via DNA folded around the stabilizing linker histones-1 (H1). Histone modification is a dynamic process controlled by the antagonistic actions of large families of enzymes, such as histone acetyltransferases (HATs), histone deacetylases (HDACs), and methyltransferases (HMTs)/demethylases (HDMTs). Histone acetyltransferases (HATs) transfer an acetyl group from an acetyl-CoA molecule to the $\mathrm{N}$ - $\varepsilon$-lysine residues of histone, resulting in the neutralization of its positive charge and in the activation of gene transcription. In contrast, histone deacetylases (HDACs) remove the acetyl group from the $\mathrm{N}-\varepsilon$-lysine residues of histone, providing a tight interaction between DNA and histone protein. This reduction of acetylation of histone 1, 3, and 4 induces chromatin changes (Figure 2). Transcription factors and RNA polymerase interact with DNA to modulate the transcription of genes. HDAC inhibitors (i.e., VPA) are able to interrupt the cell cycle, and induce growth arrest and apoptosis. Histone methylation is catalyzed by histone methyltransferases (histone-lysine $\mathrm{N}$-methyltransferases and histonearginine N-methyltransferases), which transfer one to three methyl groups from SAMe to the lysine or arginine residues of histone proteins [39].

Condense chromatin

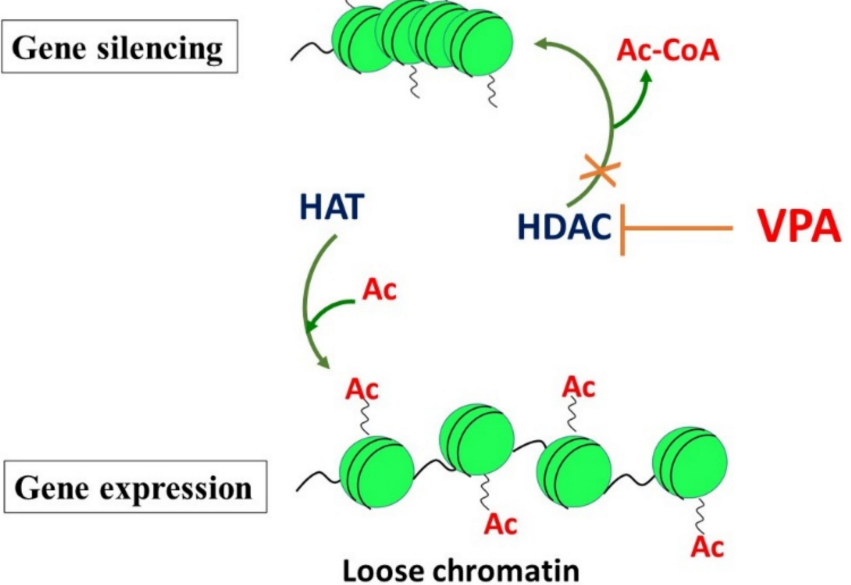

Figure 2. Effects of histones on gene silencing and activation and the role of VPA as a histone deacetylase inhibitor.

Detich et al. [33] showed that VPA triggers active demethylation of DNA in cultured human embryonic kidney cells, and that this process is not dependent on cell replication. This active demethylation is apparently achieved by acetylation of $\mathrm{H}_{3}$ histones that results from the direct action of VPA as an HDAC inhibitor, increasing the accessibility of demethylases to DNA. VPA downregulated the expression of protein kinase $\mathrm{C}$ isoforms, inducing various changes in gene expression, such as bcl-2 and Hoxa1, and activated Wnt-dependent 
gene expression [34]. VPA, similar to other histone deacetylase inhibitors, such as trichostatin A and sodium butyrate, induced apoptosis in cultured microglial cells obtained from the brains of 2-day-old rat pups [37]. It also induced epigenetic changes in the decidual cells of mice treated with a single injection of VPA. This was manifested by increased levels of acetylated histone $\mathrm{H}_{3}$, histone $\mathrm{H}_{4}$, and trimethylated $\mathrm{H} 3 \mathrm{~K} 56$ [40]. In this context, it is also interesting to note that Felisbino et al. [41] added valproic acid to hepatocytes cultured in a high-glucose (hyperglycemic) medium and found that VPA decreased the expression of genes related to the complement and coagulation cascade. The attenuation of the coagulation cascade was beneficial in reversing the increased coagulopathy induced by hyperglycemia. Thus, in this context, VPA served as an epigenetic therapeutic agent.

\subsection{Changes in Gene Expression in Offspring Induced by VPA Exposure during the Prenatal or Early Postnatal Periods}

There are relatively few studies on the changes in gene expression following prenatal treatment with VPA. Most of these changes were described in the brain of rodent offspring in studies assessing VPA-induced ASD-like behavior [42-45]. Roy et al. [42] treated mice with reduced activity of methylenetetrahydrofolate reductase (Mthfr) with a single dose of $300 \mathrm{mg} / \mathrm{kg}$ VPA on day 8.5 of gestation and compared the outcome to similarly treated normal mice. While VPA induced an increased resorption rate and dead embryos in the normal mice, in the MTHFR-deficient mice, the rate of embryonic resorptions and fetal death was similar to control saline-treated mice. VPA treatment increased MTHFR gene expression, normalizing MTHFR protein synthesis in the MTHFR-deficient mice. Similar findings were observed by Guo et al. [43], who treated young Mecp2-null mice that exhibited symptoms of Rett syndrome due to MeCP2 deficiency with $350 \mathrm{mg} / \mathrm{kg}$ VPA for 2 weeks and found significant improvement in their clinical symptoms and enhanced expression of MeCP2 gene in the brain compared to non-treated mice. These studies demonstrated the ability of VPA to induce epigenetic modifications and the possibility to use VPA for the treatment of some epigenetic diseases.

Cohen et al. [44] treated pregnant rats with a single dose of $350 \mathrm{mg} / \mathrm{kg}$ VPA on day 13 of pregnancy (post major organogenesis and closure of the neural tube) and studied the gene expression in three regions of the brain in 75-day-old offspring: the amygdala, cerebellar vermis, and orbitofrontal cerebral cortex. They found significant changes in gene expression induced by VPA, with special enrichment of genes encoding acetylationsensitive proteins, demonstrating the effects of VPA as a deacetylation inhibitor (histone deacetylase inhibitor). In addition, they found increased social investigation and play fighting in the prenatally treated rats. These behaviors increased during late adolescence. (Table 1).

Jacob et al. [45] studied the effects of $0.625 \mathrm{mM}$ of VPA on zebrafish embryos and found that VPA downregulated the proneuronal gene ascl1b, causing inhibition of serotonin synthesis in the brain. These epigenetic effects of VPA on the embryonic brain were explained by the inhibition of histone deacetylase 1 by VPA, inducing a loss of serotonergic neurons.

We treated 4-day-old ICR mice with a single intraperitoneal injection of $300 \mathrm{mg} / \mathrm{kg}$ VPA to serve as a model for ASD. We were interested in studying the possible epigenetic effects of VPA by assessing gene expression in the prefrontal cortex. In addition, we investigated the possibility that these effects can be alleviated by concomitant oral administration of $300 \mathrm{mg} / \mathrm{kg}$ SAMe during postnatal days 4-6 [17,18,30]. We found that VPA treatment indeed induced ASD-like behavior (observed on postnatal days 50-60) and also induced significant changes in the expression of many genes in the brain. These changes were different between male and female mice. Co-administration of SAMe reversed most of these molecular changes induced by VPA, demonstrating the antagonistic effect of these substances (Table 1). Postnatal treatment with SAMe did not induce significant changes in gene expression. 
Table 1. The effects of prenatal or early postnatal VPA administration to alleviate the symptoms of several epigenetic diseases.

\begin{tabular}{|c|c|c|c|}
\hline First Editor & Animals & VPA Treatment & Outcomes \\
\hline Roy et al., 2008 & $\begin{array}{l}\text { Mice with reduced } \\
\text { activity of Mthfr gene } \\
(\mathrm{Mthfr}+/-)\end{array}$ & $\begin{array}{l}\text { Single dose of } 300 \mathrm{mg} / \mathrm{kg} \text { VPA } \\
\text { on day } 8.5 \text { of pregnancy }\end{array}$ & $\begin{array}{l}\text { Increase in the expression of Mthfr gene } \\
\text { and normalization of MTHFR protein; } \\
\text { improved fetal outcome compared to } \\
\text { treated normal mice }\end{array}$ \\
\hline Guo et al., 2014 & $\begin{array}{l}\text { Six-week-old mice with } \\
\text { MECP2 deficiency (Rett } \\
\text { syndrome) }\end{array}$ & $\begin{array}{l}\text { Daily injections of } 350 \mathrm{mg} / \mathrm{kg} \\
\text { VPA for } 2 \text { weeks }\end{array}$ & $\begin{array}{l}\text { Enhanced expression of } \mathrm{MeCP} 2 \text { gene and } \\
\text { increased MeCP2 protein with } \\
\text { improvement in the clinical symptoms of } \\
\text { Rett syndrome }\end{array}$ \\
\hline Cohen et al., 2013 & Normal rats & $\begin{array}{l}350 \mathrm{mg} / \mathrm{kg} \text { VPA on day } 13 \text { of } \\
\text { gestation in normal rats }\end{array}$ & $\begin{array}{l}\text { Increased expression in the brain of genes } \\
\text { encoding for acetylation-sensitive proteins } \\
\text { and increased social investigation and play } \\
\text { fighting }\end{array}$ \\
\hline Jacob et al., 2014 & Zebrafish & $0.625 \mathrm{mM}$ VPA in water & $\begin{array}{l}\text { Downregulation of the proneuronal gene } \\
\text { ascl1b and inhibition of serotonin synthesis } \\
\text { in the brain }\end{array}$ \\
\hline Ornoy et al., 2019 & 4-day-old ICR mice & $\begin{array}{l}300 \mathrm{mg} / \mathrm{kg} \text { VPA injected to } \\
4 \text {-day-old offspring or VPA and } \\
\text { SAMe } 30 \mathrm{mg} / \mathrm{kg} \text { during } \\
\text { postnatal days } 4-6\end{array}$ & $\begin{array}{l}\text { Induction of autistic-like behavior and } \\
\text { increased oxidative stress in the prefrontal } \\
\text { cortex ameliorated by SAMe }\end{array}$ \\
\hline Weinstein et al., 2019 & 4-day-old ICR mice & $\begin{array}{l}300 \mathrm{mg} / \mathrm{kg} \text { VPA injected to } \\
\text { 4-day-old offspring or VPA and } \\
\text { SAMe } 30 \mathrm{mg} / \mathrm{kg} \text { during } \\
\text { postnatal days } 4-6\end{array}$ & $\begin{array}{l}\text { VPA induced changes in the expression of } \\
\text { neurophysiologic and neuropathlogic } \\
\text { genes in the prefrontal cortex that were } \\
\text { reversed to normal by SAMe }\end{array}$ \\
\hline
\end{tabular}

\subsection{In Summary}

VPA is a known human and animal teratogen that induces various congenital malformations, including distinct neurobehavioral abnormalities. The main mechanism of its teratogenic action is epigenetic, as it is a potent inhibitor of histone deacetylase. In the last several years, due to its epigenetic activity, it has also been used for the treatment of several cancers [46-48]. The possible use of VPA as an effective epigenetic drug in pregnancy is questionable due to its high teratogenicity. However, recent attempts to find VPA derivatives that are not teratogenic have been partially successful $[49,50]$. Such non-tertogenic derivatives with epigenetic effects will pave the way for their use as possible epigenetic drugs in pregnancy as well. It has already been shown that VPA alleviated clinical symptoms in mice with reduced activity of the Mthfr gene and in Mecp2-deficient mice that exhibit symptoms of Rett syndrome. Additional studies are needed to evaluate the abilities of VPA to serve as a human epigenetic drug especially when used in sub-teratogenic doses.

\section{S-adenosylmethionine: The Principal Physiologic Methyl Donor}

S-adenosylmethionine (SAMe, also known as AdoMet) is a natural biological active methyl donor that is involved in most methylation reactions in all living organisms [51-53]. SAMe is an important cofactor for numerous metabolic processes via three main interconnected metabolic pathways: polyamine synthesis, trans-methylation, and trans-sulfuration [51,52], and is considered second only to ATP [54]. SAMe is synthesized in the cytosol of every cell, but the liver plays the central role in the homeostasis of SAMe as the major site of its synthesis and degradation [55].

SAMe has been proposed as a potential treatment for many medical conditions, particularly major depressive disorder (MDD) [56-58], primary and secondary fibromyalgia [56,59], attention-deficit hyperactivity disorder [60], Parkinson's disease [61], and Alzheimer disease [62]. In addition, SAMe demonstrated good clinical effectiveness and was well tolerated in patients affected by osteoarthritis [63]. SAMe supplementation el- 
evates hepatic glutathione (GSH) deposits and attenuates alcohol liver disease and viral cirrhosis [64-67]. Moreover, SAMe was proven in many pre-clinical studies as a potential anticancer therapeutic [68-70]. SAMe is an FDA-approved dietary supplement in the U.S., sold without prescriptions over the counter (OTC), but in several countries in Europe, SAMe is a prescription drug. SAMe's oral bioavailability is near 2.1-2.6\% [71] and when absorbed, SAMe enters the portal circulation and is metabolized in the liver [64].

\subsection{SAMe as an Epigenetic Modulator}

Epigenetic changes are related to a variety of congenital malformations and diseases [1,72,73]. The disruption of epigenetic machinery can lead to oxidative stress, metabolic syndrome, obesity, insulin resistance, diabetes, and vascular dysfunction in humans $[74,75]$. Gene expression is regulated by complex epigenetic machinery via three main mechanisms: DNA methylation, modifications of core histone proteins, and by non-coding RNAs [4,76,77].

DNA methylation is a biochemical reaction of moving the methyl group from S-adenosyl-methionine (SAMe) to the $5^{\prime}$-position of a cytosine nucleotide linked to a guanine nucleotide (CpG) by a phosphodiester bond, usually at CpG islands, which are located in the regulatory regions of many genes, including promoters and enhancers [78]. An altered DNA methylation state, such as hypomethylation or hypermethylation, can either facilitate or inhibit the expression of genes [79]. In the healthy mammalian genome, over $85 \%$ of $\mathrm{CpG}$ dinucleotides are methylated, and this methylation rate seems to be required for appropriate maintenance of chromatin integrity and transcriptional regulation [80]. The exception is imprinted genes, where the $\mathrm{CpG}$ islands in the promoter regions are usually unmethylated. Approximately $1 \%$ to $2 \%$ of the human genome consists of CpG dinucleotides, whose methylation is inversely related to the transcriptional activity in cells [81].

SAMe is a major methyl donor for a family of DNA methyltransferases (DNMTS), with DNMT3A/DNMT3B being responsible for de novo methylation and DNMT1 recognizing hemi-methylated DNA. An increased concentration of SAMe stimulates DNA methyltransferase reactions, launching hyper-methylation of genes [82]. This hyper-methylation state of genes protects the genome against global hypomethylation and appears as a hallmark in cancer [82], Alzheimer's disease [83], and depression [84].

Reduced SAMe production and transmethylation pathways are associated with delayed brain development and severe neuropsychiatric diseases [85]. Elevated levels of SAMe in the peripheral nerves are characterized by DNA hypermethylation at the promoter and enhancer regions of several genes involved in lipid synthesis, leading to peripheral myelin defects [86]. In contrast, reduced SAMe levels are correlated with DNA demethylation in peripheral nerves. It was shown that a methionine-restricted diet led to reduced hepatic SAMe levels and may cause hepatocellular carcinoma (HCC) in mice [87]. In humans, reduced SAMe levels are associated with altered MAT activity and chronic liver disease (reviewed in [88]).

\subsection{SAMe Effects on the Embryo, Fetus, and Neonate: Its Role as an Epigenetic Modulator}

DNA methylation patterns and histone modifications during mammalian embryonic development undergo dynamic epigenetic processes required to establish the proper genomic epigenetic program. A first round of epigenetic reprogramming and genomewide changes in DNA methylation occurs immediately after fertilization and during preimplantation $[7,89,90]$. Massive DNA demethylation occurs between fertilization and the two-cell stage [89] and continues as the human embryo progresses from the morula stage to the blastocyst stage in the inner cell mass (ICM). After fertilization, the paternal genome is demethylated faster at the zygotic stage than the maternal genome, which is gradually demethylated during the development of the blastocyst. At the blastocyst stage, most methyl marks are removed, except elements regulating genomic imprinting and retroviral elements [80]. It was shown in the human embryo that in demethylated DNA, the promoter 
region of active genes associates with the presence of the trimethylation of histone $\mathrm{H} 3$ at the lysine 4 (H3K4me3) mark [89]. This genome-wide erasure of DNA methylation in the early embryo ensures that the genome is essentially devoid of epigenetic memory, which is important for setting up a pluripotent ground state and is probably regulated by histone modification epigenetic tools.

At the post-implantation stage, a second round of epigenetic changes takes place, and the level of methylation is sharply increased [89]. There is also an increase in the activity of the main de novo DNA methylation (DNMT3A/B) enzymes and of DNA methylation mark erasers, 10-11 translocation (TET1 and TET2) dioxygenases enzymes, with a simultaneous increase in $5 \mathrm{hmC}$ in the inner cell mass [91]. Failure in the function of DNMTs or TET dioxygenases may compromise normal embryonic development. The critical role of DNMTs or TET dioxygenases in normal embryonic development was demonstrated by several research studies [92,93]. Embryonic deletion of DNMT3 in neomycin conditional knockout mice results in neuronal dysfunction, associated with hypoactivity, motor abnormalities, fewer motor neurons, and a shortened lifespan [92]. Another study demonstrated that depletion of all forms of TETs in Tet triple-knockout mice arrests cell lineage differentiation and results in abnormal embryonic development [93].

The investigations of biopsies obtained from specific organs of human embryos demonstrated that the DNA methylation trajectory in the embryo undergoes considerable remodeling and modulations during the first to the second trimester of gestation $(9,18$, and 22 weeks) [6,94]. In addition, DNMTs and TET enzymes are spatially and temporally expressed during neurogenesis in the developing fetus [95]. However, the tissue-specific methylation trajectory also continues during the early postnatal period [8]. Therefore, these "critical" periods of epigenetic remodeling are extremely sensitive to environmental stimuli, leading to stable large-scale changes in the embryo's and postpartum baby's tissues.

There is a scarcity of data regarding the effects of SAMe on embryonic epigenetic remodeling. Several studies reported the effects of methionine supplementation or diet with methionine restriction that allow extrapolation of their finding to SAMe's effects, due to the conversion of methionine to SAMe by MAT enzymes. A deficiency of methionine, the precursor of SAMe, in the maternal diet causes abnormal cell metabolism through DNA hypomethylation [87]. Peñagaricano et al. [96] studied the effects of methionine supplementation on Holstein cow dams for 70 days during follicular development and early embryo development until day 7 post fertilization (Table 2). The addition of methionine to pregnant Holstein cows' diet caused a significant decrease in the expression of most genes in the preimplantation embryo, consistent with reduced transcription of genes and increased methylation of specific genes [96]. Another study demonstrated that the addition of SAMe to in vitro cultured bovine embryos from the eight-cell to the blastocyst stage caused genome-wide hypermethylation mainly in exomic regions and the CpG islands. The analysis of differentially expressed genes revealed an association with the response to nutrients and developmental processes but not with the changes in methylated regions [97].

It was demonstrated that changes in the DNA methylation state during gestation, triggered by methyl donors, could exhibit a stable phenotypic change in offspring using the viable yellow agouti (A(vy)) mouse model [98-100]. This murine agouti gene A(vy) allelic expression is dependent on the methylation state of a transposon and of a promoter region of the gene, providing researchers with an excellent animal model for exploring the effect of chemical agents on epigenetic processes during gestation [101-103]. 
Table 2. The effects of prenatal SAMe or methionine administration in pregnant animals or human.

\begin{tabular}{|c|c|c|c|}
\hline First Editor & Animal/Human & Treatment & Outcomes \\
\hline $\begin{array}{l}\text { Peñagaricano et al., } \\
2013\end{array}$ & $\begin{array}{l}\text { Holstein cows early } \\
\text { embryo }\end{array}$ & $\begin{array}{l}\text { Methionine supplementation } \\
\text { during follicular phase and } \\
\text { early embryo development, } \\
\text { until day } 7 \text {. }\end{array}$ & $\begin{array}{l}\text { In total, } 276 \text { of the 10,662 genes analyzed } \\
\text { showed significant differences following } \\
\text { treatment. Maternal methionine } \\
\text { supplementation resulted in decreased } \\
\text { expression of most genes, reduced } \\
\text { transcription, and increased methylation of } \\
\text { specific genes. }\end{array}$ \\
\hline
\end{tabular}

$\begin{array}{cll}\begin{array}{c}\text { Shojaei Saadi et al., } \\ 2002\end{array} & \begin{array}{l}\text { In vitro cultured bovine } \\ \text { embryos }\end{array} & \begin{array}{l}\text { SAMe treatment from the } \\ \text { eight-cell stage to the blastocyst } \\ \text { stage. }\end{array} \\ \text { Cooney et al., } 2002 & \begin{array}{l}\text { Viable yellow agouti } \\ \text { (A(vy)) mouse strains } \\ \text { that carry mutant alleles } \\ \text { at the agouti locus }\end{array} & \begin{array}{l}\text { Methyl donor diets: } \\ \text { betaine, choline, folic acid, B12 } \\ \text { with or without methionine, } \\ \text { and zinc during gestation. }\end{array}\end{array}$

SAMe induced genome-wide hypermethylation mainly in exonic regions and in CpG islands. Differentially expressed genes were associated with the response to nutrients and developmental processes.

The increase in offspring DNA methylation state resulted in a change from a yellow coat color distribution to a pseudo agouti coat as a result of alterations in the gene expression.

Significant gender-related changes in the expression of many genes in the brain of 1-day-old offspring. The most prominent changes in gene expression were Vegfa and its receptor Flt1.

Weinstein et al., ICR mice Oral SAMe given to DAMs on 2020 ICR mice days 12-15 of gestation.

Improved depression-like behavior at adulthood, especially in the three chamber test for sociability. Increased expression of Vegfa and its receptor Flt1 genes in the prefrontal cortex at 90 days of age.

Becker et al., 2021 Sub mice derived from $\quad(20 \mathrm{mg} / \mathrm{kg})$ on gestational days $12-14$.

\begin{tabular}{clll}
\hline $\begin{array}{c}\text { Tomáš Binder et al., } \\
1990\end{array}$ & $\begin{array}{l}\text { Pregnant Women with } \\
\text { intrahepatic cholestasis } \\
\text { of pregnancy (ICP) }\end{array}$ & $\begin{array}{l}\text { SAMe for the treatment of } \\
\text { intrahepatic cholestasis. }\end{array}$ & $\begin{array}{l}\text { No adverse effects were noted on the fetuses } \\
\text { or neonates. }\end{array}$ \\
\hline $\begin{array}{l}\text { Frezza, M et al., } \\
\text { last trimester of } \\
\text { pregnancy with } \\
\text { intrahepatic cholestasis } \\
\text { of pregnancy (ICP) }\end{array}$ & $\begin{array}{l}\text { SAMe }(800 \mathrm{mg} / \text { day i.v.) or } \\
\text { placebo until delivery for a } \\
\text { mean period of } 18 \text { days. }\end{array}$ & $\begin{array}{l}\text { No adverse reactions on mother or child } \\
\text { were recorded during SAMe treatment, and } \\
\text { at follow-up of the children. Possibly } \\
\text { decreased rate of prematurity compared to } \\
\text { placebo treated. }\end{array}$ \\
\hline Coltorti et al., 1990 & $\begin{array}{l}\text { Eighteen patients with } \\
\text { intrahepatic cholestasis } \\
\text { of pregnancy (ICP) }\end{array}$ & $\begin{array}{l}\text { SAMe } 900 \mathrm{mg} / \text { day or placebo } \\
\text { was administered by daily } \\
\text { intravenous infusions for } \\
\text { 20 days. }\end{array}$ & $\begin{array}{l}\text { No relevant adverse reactions were detected. } \\
\text { All newborns had Apgar scores greater than } \\
7 \text { and normal postnatal development. }\end{array}$ \\
\hline
\end{tabular}

Cooney et al. [98] investigated the effects of different amounts of maternal dietary methyl supplements using betaine, choline, folic acid, B12 with or without methionine, and zinc during gestation on DNA methylation and offspring's phenotype. They studied two inbred mouse strains that carried mutant alleles at the agouti locus. All these methyl donors are involved in one-carbon metabolism and regulate the synthesis of SAMe, and thereby could modulate the DNA methylation state. The methyl-donor in the maternal diet changed the offspring DNA methylome, changing the yellow coat color distribution to a pseudo agouti coat as a result of alterations in the gene expression.

SAMe, given orally to ICR mice on days 12-15 of gestation, resulted in significant gender-related changes in the expression of many genes in the brain of 1-day-old offspring [104]. The most prominent changes in gene expression were Vegfa and its receptor Flt1 (Fms-related receptor tyrosine kinase 1), which demonstrated upregulation by 390\% and $219 \%$ in males, and $272 \%$ and $292 \%$ in females, respectively [105]. A single dose of 
VPA administered to pregnant mice on day 12 of gestation almost completely reversed the effects of SAMe, and the expression of all except 4 genes was similar to controls [104].

SAMe's modulatory effects during gestation were also demonstrated by us in submissive (Sub) mice, a selectively inbred model of depression based on recurrent breeding using a social interaction and food competition paradigm [106,107]. The offspring of Sub mice that were treated by oral gavage with SAMe $(30 \mathrm{mg} / \mathrm{kg}$ ) on gestational days 12-14 demonstrated improved depression-like behavior at adulthood, especially in the Three Chamber test for sociability. This normalized social behavior was well correlated with Vegfa and its receptor Flt1 gene expression in the prefrontal cortex [108].

\subsection{SAMe and Its Possible Effects on the Pregnant Mother and Offspring}

Few studies have investigated the effects of SAMe treatment during pregnancy on the developing human embryo and fetus. Several clinical reports on the use of SAMe for the treatment of cholestasis in pregnancy demonstrated an absence of adverse effects for mothers or their infants $[51,109,110]$. Generally, the conducted clinical studies using SAMe in the pregnant population for the treatment of cholestasis support SAMe's safety for both the mother and the fetus [111].

SAMe's safety was examined in rats and New Zealand White rabbits [112] following intravenous and subcutaneous premating treatment or treatment during pregnancy and also during the peri- and post-natal periods. SAMe treatment was found to be safe, without adverse effects on either F0 or on the untreated F1 generations. In the treated dams, local tissue reaction at the injection sites and retardation of body weight gain were noted for the $400 \mathrm{mg} / \mathrm{kg}$ / day subcutaneous SAMe treatment regimen. In the intravenous studies, some rigidity and dyspnea were noted following administration. Following subcutaneous premating treatment, there was also evidence of histopathological changes in the kidneys of the female rats. However, in our studies [18,104], we did not observe any abnormal reactions of pregnant DAMs after oral SAMe administration.

\subsection{In Summary}

SAMe is an FDA-approved dietary supplement and is also approved for the treatment of major depressive disorder (MDD), osteoarthritis, and alcohol liver disease. SAMe facilitates DNA methylation by activating DNA methyltransferases that move the methyl group from SAMe to the $5^{\prime}$-position of a CpG. However, SAMe administration to pregnant women is restricted due to the lack of efficacy and safety data on the mother and embryo. Several animal studies have assessed the possible modulatory effect of SAMe during gestation on DNA methylation and gene expression and described the alleviation of several "epigenetic" neurobehavioral disorders, such as ASD and MDD, making SAMe a possible candidate for "epigenetic therapy". The existing data on the possible damaging effects of SAMe on pregnancy outcomes are negative, but these studies were carried out in the last trimester of pregnancy. There are no studies on treatment during earlier phases when the embryo and fetus may be more susceptible to possible damage. More human studies are needed in order to investigate the possible efficacy of SAMe for the treatment of "epigenetic diseases" and the mechanism(s) of its interaction with VPA.

\section{Choline and Pregnancy}

Choline is an essential micronutrient used in various metabolic and physiologic reactions and serves as the starting compound for the biosynthesis of several important metabolites. Although choline is normally synthesized in the body, the majority comes from dietary sources, both animals and plants, because the choline formed in the body is in insufficient amounts to meet all metabolic demands $[113,114]$.

During prenatal development, the demand for choline is especially high. Choline is involved in several critical processes of fetal development. During gestation, choline is involved in maternal and fetal tissue expansion [115]. It provides a substrate for the synthe- 
sis of phosphatidylcholine and sphingomyelin, major constituents of all cell membranes, and is required for brain development and fetal growth [115].

Choline also acts as a principal source of methyl groups (Figure 1). In the one-carbon cycle, choline's oxidative derivative, betaine, converts homocysteine to methionine, which is used to generate the primary methyl donor S-adenosylmethionine (SAMe). Hence, choline can exert lasting effects on gene expression via epigenetic mechanisms [114].

Choline is the precursor of acetylcholine and is therefore especially needed for fetal brain development. Choline is also involved in the regulation of neuronal proliferation, differentiation, maturation, and regulation of gene expression and neuronal survival $[116,117]$. Choline has a significant impact on brain development and cognition and may, therefore, represent a potential intervention for cognitive impairments [118].

Choline participates in membrane formation and lipid membrane integrity. In addition, choline is an enzymatic co-factor involved in the conversion of homocysteine to methionine from 5-methyltetrahydrofolate-dependent remethylation of the homocysteine pathway in the one-carbon cycle via its metabolite trimethylglycine (betaine) $[105,119]$. Choline is actively absorbed from the blood by a number of choline-like transporters that also facilitates choline uptake into the mitochondria, where choline is transformed to betaine by oxidation [120]. Methionine adenosyltransferase knockout mice, which have impaired formation of SAMe, activate the gene expressing betaine-homocysteine methyltransferase. They therefore have increased dietary choline requirements [121].

\subsection{The Impact of Choline on Pregnancy and Offspring in Rodents}

Prenatal choline deficiency in rodents is associated with changes in specific gene and protein expression [122,123] and in global DNA methylation, especially in the brain [124]. Many studies have assessed the possible neurobehavioral effects of high doses of choline during pregnancy in mice and rats. For example, Kwan et al. [125] studied the effects of maternal choline supplementation on epigenetic markers in the mouse placenta. Exposure to high choline levels (5.6 g choline chloride $/ \mathrm{kg}$ diet) during gestation altered the expression of several imprinted genes in a sex-specific manner. Choline supplementation also improved placental vascularization and perfusion [126].

Prenatal exposure to high doses of choline in rats resulted in improvement of cognitive function, spatial memory, and attentional function in offspring [127]. Treatment of pregnant rats with $25 \mathrm{mM}$ choline via drinking water from days 11-18 of pregnancy resulted in a precocious capacity for spatial navigation, whereas control rats required 3 additional days of maturation to acquire this skill. Similar results were reported by Meck et al. [128]. In contrast, mice offspring of dams that received a low-choline diet during gestation showed disrupted retinal development and visual function [129].

\subsection{Choline and Prenatal Exposure to Alcohol: Experiments in Animals}

Fetal alcohol spectrum disorder (FASD) is considered one of the major public health challenges, with an incidence range of $0.8-5 \%$ in different countries $[130,131]$. Children prenatally exposed to alcohol exhibit growth retardation, facial malformations, and central nervous system injuries, and mental retardation and cognitive deficits, such as intellectual impairments, visual-spatial learning deficits, and verbal and non-verbal memory deficits [131]. The neurobehavioral impairments found in children with FASD last into adulthood, suggesting, in addition to the well-known damage of various brain circuits, the involvement of epigenetic patterns in the persistent programming effects of fetal alcohol exposure. Furthermore, prenatal alcohol exposure is associated with distinct DNA methylation patterns in children and adolescents [132], indicating the involvement of epigenetic mechanisms in mediating the range of symptoms observed in children with FASD.

Because choline is an essential nutrient that directly affects brain development and cognition [118], choline supplementation during pregnancy or the early postnatal period may be a potential intervention for the cognitive and other impairments associated with FASD. 
Indeed, choline supplementation to animals exposed during pregnancy to high doses of ethanol generally resulted in alleviation of the damage induced by alcohol administration. For example, Steane et al. [133] treated ethanol-exposed pregnant rats with choline-supplemented chow (7.2 g choline $/ \mathrm{kg}$ chow). Choline supplementation resulted in increased fetal weight by late gestation, ameliorating the deficits caused by ethanol consumption (Table 3).

Table 3. The effects of prenatal choline administration on the neurodevelopment of rats and mice with or without exposure to prenatal ethanol (alcohol).

\begin{tabular}{|c|c|c|c|}
\hline First Editor & Rodents & Treatment & Outcome \\
\hline Albright et al., 1999 & $\begin{array}{l}\text { Sprague-Dawley rats fetal } \\
\text { brain sections were } \\
\text { collected on days } 18 \text { and } 20 \\
\text { of pregnancy }\end{array}$ & $\begin{array}{l}\text { Varying levels of dietary choline for } \\
6 \text { days from gestational day } 12 \text {. }\end{array}$ & $\begin{array}{l}\text { Choline deficiency-related brain changes } \\
\text { including an increased number of apoptotic cells } \\
\text { in the dentate gyrus and increased expression of } \\
\text { TOAD-64, a neuronal differentiation marker, in } \\
\text { the hippocampus. }\end{array}$ \\
\hline Albright et al., 2001 & $\begin{array}{l}\text { Sprague-Dawley rats fetal } \\
\text { brain sections were } \\
\text { collected on days } 18 \text { and } 20 \\
\text { of pregnancy }\end{array}$ & $\begin{array}{l}\text { Varying levels of dietary choline for } \\
6 \text { days from gestational day } 12 \text {. }\end{array}$ & $\begin{array}{l}\text { Maternal dietary choline deficiency changed the } \\
\text { localization of p15Ink4B and p27Kip1 } \\
\text { cyclin-dependent kinase inhibitors in the } \\
\text { offspring hippocampus. }\end{array}$ \\
\hline Mellott et al., 2004 & Sprague-Dawley rats & $\begin{array}{l}\text { Pregnant rats fed a } \\
\text { choline-supplemented diet for } 8 \text { days } \\
\text { (between embryonic days } 11 \text { and 18) }\end{array}$ & $\begin{array}{l}\text { Choline-supplemented rats showed evidence of } \\
\text { a precocious capacity for the spatial navigation } \\
\text { water maze task. Choline also in creased } \\
\text { activation of mitogen-activated protein kinase } \\
\text { (MAPK) and cAMP-response element binding } \\
\text { protein (CREB) in the hippocampus. }\end{array}$ \\
\hline Niculescu et al., 2006 & C57 BL/ 6 mice & $\begin{array}{l}\text { Pregnant dams fed deficient or normal } \\
\text { in choline content diet from days } 12 \text { to } \\
17 \text { of pregnancy. } \\
\text { Fetal brains collected on embryonic } \\
\text { day } 17 .\end{array}$ & $\begin{array}{l}\text { Choline deficiency increased protein levels of } \\
\text { kinase-associated phosphatase (Kap) and } \\
\text { p15INK4b (two cell cycle inhibitors) and } \\
\text { decreased gene-specific DNA methylation in the } \\
\text { offspring brain. }\end{array}$ \\
\hline Cheng et al., 2008 & Sprague-Dawley rats & $\begin{array}{l}\text { Pregnant rats fed normal choline } \\
(1.1 \mathrm{~g} / \mathrm{kg}) \text { or supplemental choline } \\
(5.0 \mathrm{~g} / \mathrm{kg}) \text { during embryonic days } \\
12-17 . \text { Male and female offspring } \\
\text { conducted behavioral training at } \\
7 \text { months of age. }\end{array}$ & $\begin{array}{l}\text { Prenatal choline supplement-action was } \\
\text { associated with an improvement of cognitive } \\
\text { function, spatial memory, and attentional } \\
\text { function }\end{array}$ \\
\hline Kwan et al., 2018 & Swiss Albino mice & $\begin{array}{l}\text { Pregnant mice fed a } 1 X \text { ( } 1.4 \mathrm{~g} \text { choline } \\
\text { chloride } / \mathrm{kg} \text { diet }) \text { or } \\
4 \mathrm{X} \text { choline ( } 5.6 \mathrm{~g} \text { choline chloride } / \mathrm{kg} \\
\text { diet) diet from embryonic day } 0.5 . \\
\text { placentas collected on embryonic } \\
\text { day } 15.5 .\end{array}$ & $\begin{array}{l}\text { High choline levels during gestation altered the } \\
\text { expression of several imprinted genes in a } \\
\text { sex-specific manner. }\end{array}$ \\
\hline $\begin{array}{l}\text { Trujillo-Gonzalez } \\
\quad \text { et al., } 2019\end{array}$ & $\begin{array}{l}\text { NestinCFPnuc } \\
\text { Nestin-CreER }{ }^{T 2}, \text { Ai9 } \\
\text { and C57BL/6J mice }\end{array}$ & $\begin{array}{l}\text { Pregnant dams randomly assigned to } \\
\text { either adequate }(1.4 \mathrm{~g} / \mathrm{kg} \text { of choline } \\
\text { chloride) or low-choline diet }(1.2 \mathrm{~g} / \mathrm{kg} \\
\text { of choline chloride) administered } \\
\text { starting at day } 11.5 \text { of pregnancy. }\end{array}$ & $\begin{array}{l}\text { Low-choline diet during gestation was } \\
\text { associated with disrupted retina development } \\
\text { and visual function. }\end{array}$ \\
\hline Steane et al., 2021 & Sprague Dawley rats & $\begin{array}{l}\text { Female rats exposed to } 12.5 \% \text { ethanol } \\
\text { from } 4 \text { days prior to } 4 \text { days after } \\
\text { conception. From day } 5 \text { of pregnancy, } \\
\text { dams were placed on different choline } \\
\text { levels chow ( } 1.6-7.2 \mathrm{~g} \text { choline } / \mathrm{kg} \\
\text { chow). Fetuses and placentas were } \\
\text { collected on day } 20 \text { of pregnancy for } \\
\text { analysis. }\end{array}$ & $\begin{array}{l}\text { Choline supplementation resulted in increased } \\
\text { fetal weight by late gestation, ameliorating the } \\
\text { deficits caused by maternal ethanol consumption }\end{array}$ \\
\hline
\end{tabular}

In a sheep model of first-trimester binge alcohol drinking, choline $(10 \mathrm{mg} / \mathrm{kg}$ in the daily food ration) administration from gestational day 4 until term mitigated the adverse neurobehavioral effects of alcohol binge drinking and additionally improved fetal appendicular bone length (femur and humerus) [134]. 


\subsection{Human Studies}

In humans, choline supplementation during pregnancy mitigated the adverse effects of heavy prenatal alcohol exposure on eyeblink conditioning, postnatal growth, and cognition as studied at 6.5 and 12 months of age [135]. Choline supplementation during pregnancy also mitigated prenatal alcohol exposure-related brain volume reductions and improved recognition memory at 12 months [136].

Kable et al. [137] followed pregnant women with reported alcohol use during pregnancy. Half of the women enrolled were assigned to receive daily prenatal vitamin $/ \mathrm{mineral}$ supplement and the other half received a daily dose of vitamin/mineral supplement combined with choline (750 mg). Vitamin/mineral combined with choline supplementation was found to significantly improve basic attentional regulation systems, such as neurophysiological encoding and memory of visual stimuli, in the first year of life. This improvement was observed in both alcohol-exposed pregnancies and non- or low alcohol-exposed pregnancies (Tables 4 and 5).

Table 4. The effects of prenatal choline administration on the neurodevelopment of children with FASD.

\begin{tabular}{|c|c|c|c|}
\hline First Editor & Participants & Treatment & Outcomes \\
\hline Ross et al., 2013 & $\begin{array}{l}100 \text { healthy pregnant } \\
\text { women and their infants. }\end{array}$ & $\begin{array}{l}\text { Phospohadtidycholine (approximately } \\
900 \mathrm{mg} \text { choline/day) from the second } \\
\text { trimester of pregnancy and } 100 \mathrm{mg} \text { until } \\
\text { the age of } 3 \text { months. }\end{array}$ & $\begin{array}{l}\text { Infants treated with choline are significantly } \\
\text { more likely to have normal cerebral inhibition } \\
\text { at } 5 \text { weeks of age. }\end{array}$ \\
\hline Kable et al., 2015 & $\begin{array}{l}\text { Pregnant women with } \\
\text { moderate/heavy } \\
\text { alcohol use. }\end{array}$ & $\begin{array}{l}750 \mathrm{mg} \text { choline }(n=37) \\
\text { multivitamin/mineral supplement } \\
(n=23) ; \text { combination of both treatments } \\
(n=19), \text { standard care }(n=35)\end{array}$ & $\begin{array}{l}\text { Multivitamin/mineral combined with choline } \\
\text { supplementation significantly improved basic } \\
\text { attentional regulation systems. }\end{array}$ \\
\hline Jacobson et al., 2018 & $\begin{array}{l}69 \text { pregnant heavy drinker } \\
\text { mothers and their infants. }\end{array}$ & $\begin{array}{l}2000 \mathrm{mg} \text { choline }(n=34 \text { or placebo } \\
(n=35) \text { from mid-pregnancy until } \\
\text { delivery }\end{array}$ & $\begin{array}{l}\text { Choline treatment improved weight, postnatal } \\
\text { growth, cognition, and eye-blink conditioning } \\
\text { at } 6.5 \text { and } 12 \text { months of age. }\end{array}$ \\
\hline Caudil et al., 2018 & $\begin{array}{l}26 \text { pregnant women } \\
\text { entering their third } \\
\text { trimester until delivery, and } \\
\text { their infants }\end{array}$ & $\begin{array}{l}\text { Either } 480 \mathrm{mg} \text { choline } / \mathrm{d}(n=13) \text { or } \\
930 \mathrm{mg} \text { choline/d }(n=13) .\end{array}$ & $\begin{array}{l}\text { Higher choline levels associated with faster } \\
\text { information processing speed in infants at } \\
4-13 \text { months. }\end{array}$ \\
\hline Freedman et al., 2019 & $\begin{array}{l}162 \text { Pregnant women with } \\
\text { different infections at } \\
16 \text { week of gestation and } \\
\text { their infants at } 1 \text { year of age }\end{array}$ & $\begin{array}{l}\text { Maternal serum choline and betaine } \\
\text { levels were measured at } 16 \text { week of } \\
\text { gestation. }\end{array}$ & $\begin{array}{l}\text { Higher gestational choline concentrations } \\
\text { were associated with improved development } \\
\text { of cerebral inhibition and cerebral regulation } \\
\text { at the age of one year. }\end{array}$ \\
\hline Warton et al., 2021 & $\begin{array}{l}52 \text { mothers with heavy } \\
\text { drinking and their infants. }\end{array}$ & $\begin{array}{l}2000 \mathrm{mg} \text { choline }(n=28) \text { or placebo } \\
(n=24) \text { from mid-pregnancy until } \\
\text { delivery. }\end{array}$ & $\begin{array}{l}\text { Choline supplementation during pregnancy } \\
\text { mitigated regional volume reductions in } \\
\text { alcohol-exposed infants, with larger volumes } \\
\text { associated with improved 12-month } \\
\text { recognition memory. }\end{array}$ \\
\hline Hunter et al., 2021 & $\begin{array}{l}122 \text { pregnant mothers and } \\
\text { their children from } \\
3 \text { months of age; } 48 \text { children } \\
\text { completed the assessment } \\
\text { at } 4 \text { years of age. }\end{array}$ & $\begin{array}{l}\text { Maternal serum choline and betaine } \\
\text { levels were measured at } 16 \text { and } \\
28 \text { weeks of gestation. }\end{array}$ & $\begin{array}{l}\text { Prenatal maternal choline levels were } \\
\text { positively associated with higher processing } \\
\text { speed and decreased problems in social } \\
\text { withdrawal. }\end{array}$ \\
\hline Cheatham et al., 2012 & $\begin{array}{l}140 \text { pregnant women } \\
\text { assigned from } 18 \text { weeks of } \\
\text { gestation, and their infants }\end{array}$ & $\begin{array}{l}750 \mathrm{mg} \text { phosphatidyl-choline }(n=49) \text { or } \\
\text { placebo }(n=50) \text { daily from } 18 \text { weeks of } \\
\text { gestation until } 90 \text { days post-partum and } \\
\text { their infants }\end{array}$ & $\begin{array}{l}\text { No significant effect of phosphatidylcholine } \\
\text { supplement detected on short-term } \\
\text { visuospatial memory, long-term episodic } \\
\text { memory, language development and global } \\
\text { development at } 10 \text { and } 12 \text { months of age. }\end{array}$ \\
\hline
\end{tabular}


Table 5. The effects of early postnatal choline administration on the neurodevelopment of children with FASD.

\begin{tabular}{|c|c|c|c|}
\hline First Editor & Participants & Treatment & Outcomes \\
\hline Wozniak et al., 2015 & $\begin{array}{l}60 \text { children aged } 2.5-5 \text { years } \\
\text { at enrollment, with FASDs }\end{array}$ & $\begin{array}{l}500 \mathrm{mg} \text { choline or placebo daily } \\
\text { for } 9 \text { months }\end{array}$ & $\begin{array}{l}\text { Choline significantly improved delayed sequential } \\
\text { memory in } 2-3 \text {-year-olds. }\end{array}$ \\
\hline Sarkar et al., 2019 & $\begin{array}{l}60 \text { children aged } 2.5-5 \text { years } \\
\text { at enrollment, with FASDs }\end{array}$ & $\begin{array}{l}500 \mathrm{mg} \text { choline or a placebo daily } \\
\text { for } 9 \text { months }\end{array}$ & $\begin{array}{l}\text { Choline supplementation reduced DNA } \\
\text { methylation of hPER } 2 \text { and hPOMC genes and } \\
\text { increased the expression of stress regulatory genes. }\end{array}$ \\
\hline $\begin{array}{l}\text { Wozniak et al., } \\
2020\end{array}$ & $\begin{array}{l}\text { Follow up of } 31 \text { children with } \\
\text { FASDs mean age } 8.6 \text { years }\end{array}$ & $\begin{array}{l}500 \mathrm{mg} \text { choline }(n=15) \text { or a } \\
\text { placebo }(n=16) \text { daily for } 9 \\
\text { months between } 2.5 \text { and } 5 \text { years }\end{array}$ & $\begin{array}{l}\text { Choline significantly improved nonverbal } \\
\text { intelligence, higher visual-spatial skills, working } \\
\text { memory ability, and verbal memory, and } \\
\text { decreased behavioral symptoms of attention deficit } \\
\text { hyperactivity disorder. }\end{array}$ \\
\hline Nguyen et al., 2016 & $\begin{array}{l}55 \text { children aged } 5-10 \text { years, } \\
\text { with confirmed histories of } \\
\text { heavy prenatal alcohol } \\
\text { exposure. }\end{array}$ & $\begin{array}{l}625 \mathrm{mg} \text { choline }(n=29) \text { or placebo } \\
(n=26) \text { daily for } 6 \text { weeks }\end{array}$ & $\begin{array}{l}\text { Choline supplementation did not improve } \\
\text { cognitive performance in any domain. }\end{array}$ \\
\hline
\end{tabular}

4.4. Human Studies Assessing the Possible Effects of Gestational Choline on Offspring in Normal Pregnancies and in Pregnancies Following High Alcohol Ingestion

Several human studies have examined the association between maternal choline intake or blood levels during pregnancy and cognitive development among their children. Contrary to the predictions from animal studies, not all human studies reported positive effects of maternal choline supplementation (Tables 4 and 5).

Positive studies: In a randomized placebo-controlled clinical trial of dietary phosphatidylcholine supplementation by Ross et al. [138], the authors treated 50 healthy pregnant women with $900 \mathrm{mg}$ choline/day, and 50 pregnant women with placebo, starting in the second trimester. They reported that at 5 weeks of age, infants treated with choline were significantly more likely to have normal cerebral inhibition in an auditory evoked-response task, a characteristic associated with a reduced risk of both attentional dysfunction and schizophrenia.

In a prospective cohort study by Boeke et al. [139], the authors estimated the associations between intakes of choline or other nutrients, such as vitamin B12, betaine, and folate, during the first and second trimesters of pregnancy and offspring visual memory at 7 years of age. Maternal gestational choline intake (but not other nutrients), especially during the second trimester of pregnancy, was positively associated with children's visual memory.

Caudill et al. [140] examined the effects of maternal choline supplementation (480 or $930 \mathrm{mg}$ / day) during the third trimester of pregnancy on infant's cognition at 4, 7, 10, and 13 months of age. They found faster information processing speed in infants during $4-13$ months in the $930(n=12)$ versus $480 \mathrm{mg}$ / day group $(n=12)$.

Freedman et al. [141] compared serum-free choline and betaine concentrations in 162 mothers with different infections during week 16 of gestation. They found significantly improved development of newborns' cerebral inhibition and behavioral regulation in 1-year-old infants born to infected mothers with higher gestational serum choline concentrations. Higher maternal plasma choline at 16 weeks of gestation was also associated with higher processing speed and decreased problems regarding social withdrawal among the children at 4 years of age (Table 4 ).

In contrast to these findings, Cheatham et al. [142] treated pregnant women with supplemental phosphatidylcholine (750 mg choline/day) or placebo from 18 weeks of gestation until postnatal day 90 . Their infants were tested for short-term visuospatial memory, long-term episodic memory, language development, and global development at 10 and 12 months of age. The authors did not find any effect of maternal or postnatal choline supplementation on infants' brain function. 


\subsection{Early Postnatal Choline Treatment of Children with FASD}

Several studies have evaluated the effects of choline supplementation on young children prenatally exposed to alcohol. The results are controversial (Table 5).

Positive results were reported by Wozniac et al. [143] in a cohort of 51 preschoolaged children with FASD treated daily with $500 \mathrm{mg}$ choline or with placebo for 9 months. Choline supplementation improved the memory function in children between the ages of 2.5 and 5 years. Later, at a mean age of 8.5 years, 31 of the children (16 placebo, 15 choline) underwent measurements of their intelligence, memory, executive functioning, and behavior [16]. Children who received choline had higher non-verbal intelligence, higher visual-spatial skills, higher working memory ability, better verbal memory, and fewer behavioral symptoms of attention deficit hyperactivity disorder than the placebo group. In the same group of children with FASD, choline supplementation also reduced DNA methylation and increased the expression of stress regulatory genes (PER2 and POMC) [144], emphasizing the epigenetic influence of choline.

In contrast to these positive findings, Nguyen et al. [145] studied 55 children aged 5-10 years that were exposed prenatally to heavy maternal alcohol drinking. They received either $625 \mathrm{mg}$ choline/day for 6 weeks $(n=29)$ or placebo $(n=26)$. The children were administered a standardized neuropsychological test battery before and immediately after the intervention. The authors reported that choline-treated children did not differentially improve in cognitive performance in any domain, including learning and memory, executive function, and sustained attention. The negative results could be explained by the short treatment duration. More studies are needed to properly evaluate the possible effects of choline treatment on children with FASD.

\subsection{In Summary}

Positive effects of prenatal choline supplementation were described in several studies, indicating the possible benefits of choline dietary intake during pregnancy in regulating the cognitive functions of offspring, especially in children with FASD. There seems to be no damaging effects of choline on the course of pregnancy or on the conceptus. Because of the limited number of studies that have explored the effects of prenatal and postnatal dietary choline interventions and their controversial results, more research is needed to reach conclusions about its effectiveness and to find the optimal supplementation dosage and periods. Once the data are clear, it will be possible to better judge the efficacy of choline in pregnancy for possible "epigenetic therapy".

\section{Discussion and Conclusions}

We described the main effects of three agents that have the ability to induce epigenetic modifications: valproic acid, a well-established human teratogen that is contraindicated in pregnancy unless doses lower than $600 \mathrm{mg}$ /day are used; S-adenosylmethionine (SAMe); and choline. These substances are known for their involvement in the processes of gene activation and silencing as they are important components of one carbon metabolism (SAMe and choline) and histone functions (VPA). SAMe and VPA seem to have antagonistic effects on gene expression, as evidenced in animal experiments. Additional important substances involved in the one carbon cycle are methionine and folic acid, which may also serve as "epigenetic drugs", but they are not discussed in this review.

SAMe, a recognized food additive, has been successfully used in the last years as an adjunct therapy for several psychiatric disorders and choline is a well-recognized food additive. However, we are still far away from their use as epigenetic modulators or their regular use in medical practice. The daily adult dose of SAMe is $400-800 \mathrm{mg}$, that of choline is 500-1000 mg, and the daily dose of VPA in pregnancy should not exceed $600 \mathrm{mg}$ due to its high teratogenicity. Studies have shown that each of these substances is able to alleviate the severity of neurobehavioral symptoms in animal models of diseases, such as ASD, MDD, MTHFR deficiency, Rett syndrome, and alcoholic embryopathy, by inducing changes in the expression of affected genes or by other, yet unknown, mechanisms. However, we 
are still missing clinical trials that might enable the translation of the beneficial effects of these substances to the treatment of human "epigenetic diseases".

Author Contributions: A.O. wrote the introduction, description of VPA, summary and conclusions and supervised the manuscript. M.B. wrote the part that refers to SAMe, L.W.-F. wrote the part and tables that refer to choline. All authors have read and agreed to the published version of the manuscript.

Funding: This research received no external funding.

Institutional Review Board Statement: Not applicable.

Informed Consent Statement: Not applicable.

Data Availability Statement: Data sharing not applicable.

Conflicts of Interest: None of the authors has any conflict of interest in the preparation of this manuscript.

$\begin{array}{ll}\text { Abbreviations } \\ \text { A(vy) } & \text { viable yellow agouti mice } \\ \text { ASD } & \text { Autism spectrum disorder } \\ \text { DNMTS } & \text { DNA methyltransferases } \\ \text { FASD } & \text { Fetal alcohol spectrum disorder } \\ \text { Flt1 } & \text { Fms related receptor tyrosine kinase 1 } \\ \text { GSH } & \text { Hepatic glutathione } \\ \text { HCC } & \text { Hepatocellular carcinoma } \\ \text { HDAC } & \text { Histone deacetylases } \\ \text { ICM } & \text { Inner cell mass } \\ \text { MAT } & \text { Methionine adenosyltransferase } \\ \text { MDD } & \text { Major depressive disorder } \\ \text { MTHFR } & \text { Methylenetetrahydrofolate reductase } \\ \text { SAMe } & \text { S-adenosylmethionine } \\ \text { Sub } & \text { Submissive mice } \\ \text { TET } & \text { Ten-eleven translocation dioxygenases } \\ \text { VEGF } & \text { Vascular endothelial growth factor } \\ \text { VPA } & \text { Valproic acid }\end{array}$

\section{References}

1. Szyf, M. Prospects for the development of epigenetic drugs for CNS conditions. Nat. Rev. Drug Discov. 2015, 14, 461-474. [CrossRef]

2. Chiarella, J.; Schumann, L.; Pomares, F.B.; Frodl, T.; Tozzi, L.; Nemoda, Z.; Yu, P.; Szyf, M.; Khalid-Khan, S.; Booij, L. DNA methylation differences in stress-related genes, functional connectivity and gray matter volume in depressed and healthy adolescents. J. Affect. Disord. 2020, 271, 160-168. [CrossRef]

3. Petropoulos, S.; Guillemin, C.; Ergaz, Z.; Dimov, S.; Suderman, M.; Weinstein-Fudim, L.; Ornoy, A.; Szyf, M. Gestational Diabetes Alters Offspring DNA Methylation Profiles in Human and Rat: Identification of Key Pathways Involved in Endocrine System Disorders, Insulin Signaling, Diabetes Signaling, and ILK Signaling. Endocrinology 2015, 156, 2222-2238. [CrossRef] [PubMed]

4. Szyf, M. Perinatal stress and epigenetics. Handb. Clin. Neurol. 2021, 180, 125-148. [CrossRef]

5. Ornoy, A. Valproic acid in pregnancy: How much are we endangering the embryo and fetus? Reprod. Toxicol. 2009, 28, 1-10. [CrossRef] [PubMed]

6. $\quad$ Roost, M.S.; Slieker, R.C.; Bialecka, M.; van Iperen, L.; Gomes Fernandes, M.M.; He, N.; Suchiman, H.E.D.; Szuhai, K.; Carlotti, F.; de Koning, E.J.P.; et al. DNA methylation and transcriptional trajectories during human development and reprogramming of isogenic pluripotent stem cells. Nat. Commun. 2017, 8, 908. [CrossRef] [PubMed]

7. Xia, W.; Xie, W. Rebooting the Epigenomes during Mammalian Early Embryogenesis. Stem Cell Rep. 2020, 15, 1158-1175. [CrossRef] [PubMed]

8. Reizel, Y.; Sabag, O.; Skversky, Y.; Spiro, A.; Steinberg, B.; Bernstein, D.; Wang, A.; Kieckhaefer, J.; Li, C.; Pikarsky, E.; et al. Postnatal DNA demethylation and its role in tissue maturation. Nat. Commun. 2018, 9, 2040. [CrossRef]

9. Nagy, C.; Turecki, G. Sensitive periods in epigenetics: Bringing us closer to complex behavioral phenotypes. Epigenomics 2012, 4, 445-457. [CrossRef]

10. Burns, S.B.; Szyszkowicz, J.K.; Luheshi, G.N.; Lutz, P.E.; Turecki, G. Plasticity of the epigenome during early-life stress. Semin. Cell Dev. Biol. 2018, 77, 115-132. [CrossRef] 
11. Ornoy, A.; Ergaz, Z. Alcohol abuse in pregnant women: Effects on the fetus and newborn, mode of action and maternal treatment. Int. J. Environ. Res. Public Health 2010, 7, 364-379. [CrossRef] [PubMed]

12. Rice, D.; Barone, S., Jr. Critical periods of vulnerability for the developing nervous system: Evidence from humans and animal models. Environ. Health Perspect. 2000, 108 (Suppl. 3), 511-533. [CrossRef] [PubMed]

13. Lucassen, P.J.; Naninck, E.F.; van Goudoever, J.B.; Fitzsimons, C.; Joels, M.; Korosi, A. Perinatal programming of adult hippocampal structure and function; emerging roles of stress, nutrition and epigenetics. Trends Neurosci. 2013, 36, 621-631. [CrossRef] [PubMed]

14. Li, L.; Maire, C.L.; Bilenky, M.; Carles, A.; Heravi-Moussavi, A.; Hong, C.; Tam, A.; Kamoh, B.; Cho, S.; Cheung, D.; et al Epigenomic programming in early fetal brain development. Epigenomics 2020, 12, 1053-1070. [CrossRef]

15. Bottom, R.T.; Abbott, C.W., 3rd; Huffman, K.J. Rescue of ethanol-induced FASD-like phenotypes via prenatal co-administration of choline. Neuropharmacology 2020, 168, 107990. [CrossRef]

16. Wozniak, J.R.; Fink, B.A.; Fuglestad, A.J.; Eckerle, J.K.; Boys, C.J.; Sandness, K.E.; Radke, J.P.; Miller, N.C.; Lindgren, C.; Brearley, A.M.; et al. Four-year follow-up of a randomized controlled trial of choline for neurodevelopment in fetal alcohol spectrum disorder. J. Neurodev. Disord. 2020, 12, 9. [CrossRef]

17. Ornoy, A.; Weinstein-Fudim, L.; Tfilin, M.; Ergaz, Z.; Yanai, J.; Szyf, M.; Turgeman, G. S-adenosyl methionine prevents ASD like behaviors triggered by early postnatal valproic acid exposure in very young mice. Neurotoxicol. Teratol. 2019, 71, 64-74. [CrossRef] [PubMed]

18. Weinstein-Fudim, L.; Ergaz, Z.; Turgeman, G.; Yanai, J.; Szyf, M.; Ornoy, A. Gender Related Changes in Gene Expression Induced by Valproic Acid in A Mouse Model of Autism and the Correction by S-adenosyl Methionine. Does It Explain the Gender Differences in Autistic Like Behavior? Int. J. Mol. Sci. 2019, 20, 5278. [CrossRef]

19. Tran, L.N.K.; Kichenadasse, G.; Morel, K.L.; Lavranos, T.C.; Klebe, S.; Lower, K.M.; Ormsby, R.J.; Elliot, D.J.; Sykes, P.J. The Combination of Metformin and Valproic Acid Has a Greater Anti-tumoral Effect on Prostate Cancer Growth In Vivo than Either Drug Alone. Vivo 2019, 33, 99-108. [CrossRef]

20. Kaaja, E.; Kaaja, R.; Hiilesmaa, V. Major malformations in offspring of women with epilepsy. Neurology 2003, 60, 575-579. [CrossRef]

21. Vajda, F.J.; Hitchcock, A.; Graham, J.; O’Brien, T.; Lander, C.; Eadie, M. The Australian Register of Antiepileptic Drugs in Pregnancy: The first 1002 pregnancies. Aust. N. Z. J. Obstet. Gynaecol. 2007, 47, 468-474. [CrossRef]

22. Bromfield, E.B.; Dworetzky, B.A.; Wyszynski, D.F.; Smith, C.R.; Baldwin, E.J.; Holmes, L.B. Valproate teratogenicity and epilepsy syndrome. Epilepsia 2008, 49, 2122-2124. [CrossRef]

23. Rasalam, A.D.; Hailey, H.; Williams, J.H.; Moore, S.J.; Turnpenny, P.D.; Lloyd, D.J.; Dean, J.C. Characteristics of fetal anticonvulsant syndrome associated autistic disorder. Dev. Med. Child Neurol. 2005, 47, 551-555. [CrossRef]

24. Christensen, J.; Grønborg, T.K.; Sørensen, M.J.; Schendel, D.; Parner, E.T.; Pedersen, L.H.; Vestergaard, M. Prenatal valproate exposure and risk of autism spectrum disorders and childhood autism. JAMA 2013, 309, 1696-1703. [CrossRef]

25. Binkerd, P.E.; Rowland, J.M.; Nau, H.; Hendrickx, A.G. Evaluation of valproic acid (VPA) developmental toxicity and pharmacokinetics in Sprague-Dawley rats. Fundam. Appl. Toxicol. 1988, 11, 485-493. [CrossRef]

26. Wagner, G.C.; Reuhl, K.R.; Cheh, M.; McRae, P.; Halladay, A.K. A new neurobehavioral model of autism in mice: Pre- and postnatal exposure to sodium valproate. J. Autism Dev. Disord. 2006, 36, 779-793. [CrossRef]

27. Rodier, P.M.; Ingram, J.L.; Tisdale, B.; Nelson, S.; Romano, J. Embryological origin for autism: Developmental anomalies of the cranial nerve motor nuclei. J. Comp. Neurol. 1996, 370, 247-261. [CrossRef]

28. Ingram, J.L.; Peckham, S.M.; Tisdale, B.; Rodier, P.M. Prenatal exposure of rats to valproic acid reproduces the cerebellar anomalies associated with autism. Neurotoxicol. Teratol. 2000, 22, 319-324. [CrossRef]

29. Welsh, J.P.; Ahn, E.S.; Placantonakis, D.G. Is autism due to brain desynchronization? Int. J. Dev. Neurosci. 2005, 23, 253-263. [CrossRef]

30. Weinstein-Fudim, L.; Ergaz, Z. Prevention or Amelioration of Autism-Like Symptoms in Animal Models: Will it Bring Us Closer to Treating Human ASD? Int. J. Mol. Sci. 2019, 20, 1074.

31. Choi, C.S.; Gonzales, E.L.; Kim, K.C.; Yang, S.M.; Kim, J.W.; Mabunga, D.F.; Cheong, J.H.; Han, S.H.; Bahn, G.H.; Shin, C.Y. The transgenerational inheritance of autism-like phenotypes in mice exposed to valproic acid during pregnancy. Sci. Rep. 2016, 6 , 36250. [CrossRef]

32. Phiel, C.J.; Zhang, F.; Huang, E.Y.; Guenther, M.G.; Lazar, M.A.; Klein, P.S. Histone deacetylase is a direct target of valproic acid, a potent anticonvulsant, mood stabilizer, and teratogen. J. Biol. Chem. 2001, 276, 36734-36741. [CrossRef]

33. Detich, N.; Bovenzi, V.; Szyf, M. Valproate induces replication-independent active DNA demethylation. J. Biol. Chem. 2003, 278, 27586-27592. [CrossRef]

34. Wiltse, J. Mode of action: Inhibition of histone deacetylase, altering WNT-dependent gene expression, and regulation of beta-catenin-Developmental effects of valproic acid. Crit. Rev. Toxicol. 2005, 35, 727-738. [CrossRef]

35. Gurvich, N.; Berman, M.G.; Wittner, B.S.; Gentleman, R.C.; Klein, P.S.; Green, J.B. Association of valproate-induced teratogenesis with histone deacetylase inhibition in vivo. FASEB J. 2005, 19, 1166-1168. [CrossRef]

36. Menegola, E.; Di Renzo, F.; Broccia, M.L.; Giavini, E. Inhibition of histone deacetylase as a new mechanism of teratogenesis. Birth Defects Res. Part C Embryo Today 2006, 78, 345-353. [CrossRef] 
37. Chen, P.S.; Wang, C.C.; Bortner, C.D.; Peng, G.S.; Wu, X.; Pang, H.; Lu, R.B.; Gean, P.W.; Chuang, D.M.; Hong, J.S. Valproic acid and other histone deacetylase inhibitors induce microglial apoptosis and attenuate lipopolysaccharide-induced dopaminergic neurotoxicity. Neuroscience 2007, 149, 203-212. [CrossRef]

38. Quina, A.S.; Buschbeck, M.; Di Croce, L. Chromatin structure and epigenetics. Biochem. Pharmacol. 2006, 72, 1563-1569. [CrossRef]

39. Bannister, A.J.; Kouzarides, T. Reversing histone methylation. Nature 2005, 436, 1103-1106. [CrossRef]

40. Shafique, S.; Winn, L.M. Gestational valproic acid exposure induces epigenetic modifications in murine decidua. Placenta 2021, 107, 31-40. [CrossRef]

41. Felisbino, M.B.; Ziemann, M.; Khurana, I.; Okabe, J.; Al-Hasani, K.; Maxwell, S.; Harikrishnan, K.N.; de Oliveira, C.B.M.; Mello, M.L.S.; El-Osta, A. Valproic acid influences the expression of genes implicated with hyperglycaemia-induced complement and coagulation pathways. Sci. Rep. 2021, 11, 2163. [CrossRef]

42. Roy, M.; Leclerc, D.; Wu, Q.; Gupta, S.; Kruger, W.D.; Rozen, R. Valproic acid increases expression of methylenetetrahydrofolate reductase (MTHFR) and induces lower teratogenicity in MTHFR deficiency. J. Cell. Biochem. 2008, 105, 467-476. [CrossRef]

43. Guo, W.; Tsujimura, K.; Otsuka, I.M.; Irie, K.; Igarashi, K.; Nakashima, K.; Zhao, X. VPA alleviates neurological deficits and restores gene expression in a mouse model of Rett syndrome. PLOS ONE 2014, 9, e100215. [CrossRef]

44. Cohen, O.S.; Varlinskaya, E.I.; Wilson, C.A.; Glatt, S.J.; Mooney, S.M. Acute prenatal exposure to a moderate dose of valproic acid increases social behavior and alters gene expression in rats. Int. J. Dev. Neurosci. 2013, 31, 740-750. [CrossRef]

45. Jacob, J.; Ribes, V.; Moore, S.; Constable, S.C.; Sasai, N.; Gerety, S.S.; Martin, D.J.; Sergeant, C.P.; Wilkinson, D.G.; Briscoe, J. Valproic acid silencing of ascl1b/Ascl1 results in the failure of serotonergic differentiation in a zebrafish model of fetal valproate syndrome. Dis. Models Mech. 2014, 7, 107-117. [CrossRef]

46. Heers, H.; Stanislaw, J.; Harrelson, J.; Lee, M.W. Valproic acid as an adjunctive therapeutic agent for the treatment of breast cancer. Eur. J. Pharmacol. 2018, 835, 61-74. [CrossRef]

47. Jahani, M.; Khanahmad, H.; Nikpour, P. Evaluation of the Effects of Valproic Acid Treatment on Cell Survival and EpithelialMesenchymal Transition-Related Features of Human Gastric Cancer Cells. J. Gastrointest. Cancer 2021, 52, 676-681. [CrossRef]

48. Gilardini Montani, M.S.; Granato, M.; Santoni, C.; Del Porto, P.; Merendino, N.; D’Orazi, G.; Faggioni, A.; Cirone, M. Histone deacetylase inhibitors VPA and TSA induce apoptosis and autophagy in pancreatic cancer cells. Cell Oncol. 2017, 40, 167-180. [CrossRef]

49. Gravemann, U.; Volland, J.; Nau, H. Hydroxamic acid and fluorinated derivatives of valproic acid: Anticonvulsant activity, neurotoxicity and teratogenicity. Neurotoxicol. Teratol. 2008, 30, 390-394. [CrossRef]

50. Modi, H.R.; Basselin, M.; Rapoport, S.I. Valnoctamide, a non-teratogenic amide derivative of valproic acid, inhibits arachidonic acid activation in vitro by recombinant acyl-CoA synthetase-4. Bipolar Disord. 2014, 16, 875-880. [CrossRef]

51. Binder, T.; Salaj, P.; Zima, T.; Vítek, L. Randomized prospective comparative study of ursodeoxycholic acid and S-adenosyl-Lmethionine in the treatment of intrahepatic cholestasis of pregnancy. J. Perinat. Med. 2006, 34, 383-391. [CrossRef]

52. Lu, S.C. S-Adenosylmethionine. Int. J. Biochem. Cell Biol. 2000, 32, 391-395. [CrossRef]

53. Panmanee, J.; Bradley-Clarke, J.; Mato, J.M.; O’Neill, P.M.; Antonyuk, S.V.; Hasnain, S.S. Control and regulation of SAdenosylmethionine biosynthesis by the regulatory $\beta$ subunit and quinolone-based compounds. FEBS J. 2019, 286, 2135-2154. [CrossRef]

54. Cantoni, G.L. Biological methylation: Selected aspects. Annu. Rev. Biochem. 1975, 44, 435-451. [CrossRef]

55. Mato, J.; Alvarez, L.; Ortiz, P.; Pajares, M.A. S-adenosylmethionine synthesis: Molecular mechanisms and clinical implications. Pharmacol. Ther. 1997, 73, 265-280. [CrossRef]

56. De Berardis, D.; Orsolini, L.; Serroni, N.; Girinelli, G.; Iasevoli, F.; Tomasetti, C.; de Bartolomeis, A.; Mazza, M.; Valchera, A.; Fornaro, M.; et al. A comprehensive review on the efficacy of S-Adenosyl-L-methionine in Major Depressive Disorder. CNS Neurol. Disord. Drug Targets 2016, 15, 35-44. [CrossRef]

57. Cuomo, A.; Beccarini Crescenzi, B.; Bolognesi, S.; Goracci, A.; Koukouna, D.; Rossi, R.; Fagiolini, A. S-Adenosylmethionine (SAMe) in major depressive disorder (MDD): A clinician-oriented systematic review. Ann. Gen. Psychiatry 2020, 19, 50. [CrossRef]

58. Sarris, J.; Murphy, J.; Stough, C.; Mischoulon, D.; Bousman, C.; MacDonald, P.; Adams, L.; Nazareth, S.; Oliver, G.; Cribb, L.; et al. S-Adenosylmethionine (SAMe) monotherapy for depression: An 8-week double-blind, randomised, controlled trial. Psychopharmacology 2020, 237, 209-218. [CrossRef]

59. Jacobsen, S.; Danneskiold-samsøe, B.; Andersen, R.B. Oral S-adenosylmethionine in Primary Fibromyalgia. Double-blind Clinical Evaluation. Scand. J. Rheumatol. 1991, 20, 294-302. [CrossRef]

60. Shekim, W.O.; Antun, F.; Hanna, G.L.; McCracken, J.T.; Hess, E.B. S-adenosyl-L-methionine (SAM) in adults with ADHD, RS: Preliminary results from an open trial. Psychopharmacol. Bull. 1990, 26, 249-253.

61. Di Rocco, A.; Rogers, J.D.; Brown, R.; Werner, P.; Bottiglieri, T. S-Adenosyl-Methionine improves depression in patients with Parkinson's disease in an open-label clinical trial. Mov. Disord. 2000, 15, 1225-1229. [CrossRef]

62. Beauchamp, L.C.; Liu, X.M.; Sedjahtera, A.; Bogeski, M.; Vella, L.J.; Bush, A.I.; Adlard, P.A.; Barnham, K.J. S-Adenosylmethionine Rescues Cognitive Deficits in the rTg4510 Animal Model by Stabilizing Protein Phosphatase 2A and Reducing Phosphorylated Tau. J. Alzheimer's Dis. JAD 2020, 77, 1705-1715. [CrossRef] [PubMed]

63. König, B. A long-term (two years) clinical trial with S-adenosylmethionine for the treatment of osteoarthritis. Am. J. Med. 1987, 83, 89-94. [CrossRef]

64. Friedel, H.A.; Goa, K.L.; Benfield, P. S-Adenosyl-L-Methionine. Drugs 1989, 38, 389-416. [CrossRef] [PubMed] 
65. Fernández, L.; Pérez, V.; Muñoz, M.; Corpa, J.M.; Abad, M.; Carbajo, M.T. Effects of S-adenosylmethionine on hepatic regeneration after partial hepatectomy in the rat. J. Physiol. Biochem. 2003, 59, 63-64. [CrossRef]

66. Purohit, V.; Abdelmalek, M.F.; Barve, S.; Benevenga, N.J.; Halsted, C.H.; Kaplowitz, N.; Kharbanda, K.K.; Liu, Q.-Y.; Lu, S.C.; McClain, C.J.; et al. Role of S-adenosylmethionine, folate, and betaine in the treatment of alcoholic liver disease: Summary of a symposium. Am. J. Clin. Nutr. 2007, 86, 14-24. [CrossRef] [PubMed]

67. Qiao, J.; Zhao, C. Therapeutic effect of adenosylmethionine on viral hepatitis and related factors inducing diseas. Am. J. Transl. Res. 2021, 13, 9485-9494.

68. Ilisso, C.P.; Sapio, L.; Delle Cave, D.; Illiano, M.; Spina, A.; Cacciapuoti, G.; Naviglio, S.; Porcelli, M. S-Adenosylmethionine Affects ERK1/2 and Stat3 Pathways and Induces Apotosis in Osteosarcoma Cells. J. Cell. Physiol. 2016, 231, 428-435. [CrossRef] [PubMed]

69. Mahmood, N.; Cheishvili, D.; Arakelian, A.; Tanvir, I.; Khan, H.A.; Pépin, A.S.; Szyf, M.; Rabbani, S.A. Methyl donor Sadenosylmethionine (SAM) supplementation attenuates breast cancer growth, invasion, and metastasis in vivo; therapeutic and chemopreventive applications. Oncotarget 2018, 9, 5169-5183. [CrossRef]

70. Ilisso, C.P.; Castellano, M.; Zappavigna, S.; Lombardi, A.; Vitale, G.; Dicitore, A.; Cacciapuoti, G.; Caraglia, M.; Porcelli, M. The methyl donor S-adenosylmethionine potentiates doxorubicin effects on apoptosis of hormone-dependent breast cancer cell lines Endocrine 2015, 50, 212-222. [CrossRef]

71. Yang, J.; He, Y.; Du, Y.X.; Tang, L.L.; Wang, G.J.; Fawcett, J.P. Pharmacokinetic properties of S-adenosylmethionine after oral and intravenous administration of its tosylate disulfate salt: A multiple-dose, open-label, parallel-group study in healthy Chinese volunteers. Clin. Ther. 2009, 31, 311-320. [CrossRef]

72. Ornoy, A.; Weinstein-Fudim, L.; Ergaz, Z. Prenatal factors associated with autism spectrum disorder (ASD). Reprod. Toxicol. 2015, 56, 155-169. [CrossRef]

73. Cavalli, G.; Heard, E. Advances in epigenetics link genetics to the environment and disease. Nature 2019, 571, 489-499. [CrossRef] [PubMed]

74. Smith, C.J.; Ryckman, K.K. Epigenetic and developmental influences on the risk of obesity, diabetes, and metabolic syndrome Diabetes Metab. Syndr. Obes. 2015, 8, 295-302. [CrossRef] [PubMed]

75. Maude, H.; Sanchez-Cabanillas, C.; Cebola, I. Epigenetics of Hepatic Insulin Resistance. Front. Endocrinol. 2021, 12, 504. [CrossRef] [PubMed]

76. Frías-Lasserre, D.; Villagra, C.A. The Importance of ncRNAs as Epigenetic Mechanisms in Phenotypic Variation and Organic Evolution. Front. Microbiol. 2017, 8, 2483. [CrossRef]

77. Corso-Díaz, X.; Jaeger, C.; Chaitankar, V.; Swaroop, A. Epigenetic control of gene regulation during development and disease: A view from the retina. Prog. Retin. Eye Res. 2018, 65, 1-27. [CrossRef]

78. Dindot, S.V.; Person, R.; Strivens, M.; Garcia, R.; Beaudet, A.L. Epigenetic profiling at mouse imprinted gene clusters reveals novel epigenetic and genetic features at differentially methylated regions. Genome Res. 2009, 19, 1374-1383. [CrossRef]

79. Matouk, C.C.; Marsden, P.A. Epigenetic regulation of vascular endothelial gene expression. Circ. Res. 2008, 102, 873-887. [CrossRef]

80. Golding, M.C.; Williamson, G.L.; Stroud, T.K.; Westhusin, M.E.; Long, C.R. Examination of DNA methyltransferase expression in cloned embryos reveals an essential role for Dnmt1 in bovine development. Mol. Reprod. Dev. 2011, 78, 306-317. [CrossRef]

81. Warner, M.J.; Ozanne, S.E. Mechanisms involved in the developmental programming of adulthood disease. Biochem. J. 2010, 427, 333-347. [CrossRef] [PubMed]

82. Wang, Y.; Sun, Z.; Szyf, M. S-adenosyl-methionine (SAM) alters the transcriptome and methylome and specifically blocks growth and invasiveness of liver cancer cells. Oncotarget 2017, 8, 111866-111881. [CrossRef] [PubMed]

83. Chouliaras, L.; Mastroeni, D.; Delvaux, E.; Grover, A.; Kenis, G.; Hof, P.R.; Steinbusch, H.W.; Coleman, P.D.; Rutten, B.P.; van den Hove, D.L. Consistent decrease in global DNA methylation and hydroxymethylation in the hippocampus of Alzheimer's disease patients. Neurobiol. Aging 2013, 34, 2091-2099. [CrossRef] [PubMed]

84. Numata, S.; Ishii, K.; Tajima, A.; Iga, J.; Kinoshita, M.; Watanabe, S.; Umehara, H.; Fuchikami, M.; Okada, S.; Boku, S.; et al. Blood diagnostic biomarkers for major depressive disorder using multiplex DNA methylation profiles: Discovery and validation. Epigenetics 2015, 10, 135-141. [CrossRef] [PubMed]

85. Indika, N.-L.R.; Deutz, N.E.P.; Engelen, M.P.K.J.; Peiris, H.; Wijetunge, S.; Perera, R. Sulfur amino acid metabolism and related metabotypes of autism spectrum disorder: A review of biochemical evidence for a hypothesis. Biochimie 2021, 184, 143-157. [CrossRef]

86. Varela-Rey, M.; Iruarrizaga-Lejarreta, M.; Lozano, J.J.; Aransay, A.M.; Fernandez, A.F.; Lavin, J.L.; Mósen-Ansorena, D.; Berdasco, M.; Turmaine, M.; Luka, Z.; et al. S-adenosylmethionine Levels Regulate the Schwann Cell DNA Methylome. Neuron 2014, 81, 1024-1039. [CrossRef]

87. Wilson, M.J.; Shivapurkar, N.; Poirier, L.A. Hypomethylation of hepatic nuclear DNA in rats fed with a carcinogenic methyldeficient diet. Biochem. J. 1984, 218, 987-990. [CrossRef]

88. Lu, S.C.; Mato, J.M. S-adenosylmethionine in liver health, injury, and cancer. Physiol. Rev. 2012, 92, 1515-1542. [CrossRef]

89. Guo, H.; Zhu, P.; Yan, L.; Li, R.; Hu, B.; Lian, Y.; Yan, J.; Ren, X.; Lin, S.; Li, J.; et al. The DNA methylation landscape of human early embryos. Nature 2014, 511, 606-610. [CrossRef] 
90. Smith, Z.D.; Chan, M.M.; Humm, K.C.; Karnik, R.; Mekhoubad, S.; Regev, A.; Eggan, K.; Meissner, A. DNA methylation dynamics of the human preimplantation embryo. Nature 2014, 511, 611-615. [CrossRef]

91. Lee, H.J.; Hore, T.A.; Reik, W. Reprogramming the methylome: Erasing memory and creating diversity. Cell Stem Cell 2014, 14, 710-719. [CrossRef] [PubMed]

92. Nguyen, S.; Meletis, K.; Fu, D.; Jhaveri, S.; Jaenisch, R. Ablation of de novo DNA methyltransferase Dnmt3a in the nervous system leads to neuromuscular defects and shortened lifespan. Dev. Dyn. 2007, 236, 1663-1676. [CrossRef] [PubMed]

93. Dawlaty, M.M.; Breiling, A.; Le, T.; Barrasa, M.I.; Raddatz, G.; Gao, Q.; Powell, B.E.; Cheng, A.W.; Faull, K.F.; Lyko, F.; et al. Loss of Tet Enzymes Compromises Proper Differentiation of Embryonic Stem Cells. Dev. Cell 2014, 29, 102-111. [CrossRef] [PubMed]

94. Slieker, R.C.; Roost, M.S.; van Iperen, L.; Suchiman, H.E.D.; Tobi, E.W.; Carlotti, F.; de Koning, E.J.P.; Slagboom, P.E.; Heijmans, B.T.; Chuva de Sousa Lopes, S.M. DNA Methylation Landscapes of Human Fetal Development. PLoS Genet. 2015, 11, e1005583. [CrossRef] [PubMed]

95. Chen, J.H.; Zheng, Y.L.; Xu, C.Q.; Gu, L.Z.; Ding, Z.L.; Qin, L.; Wang, Y.; Fu, R.; Wan, Y.F.; Hu, C.P. Valproic acid (VPA) enhances cisplatin sensitivity of non-small cell lung cancer cells via HDAC2 mediated down regulation of ABCA1. Biol. Chem. 2017, 398, 785-792. [CrossRef]

96. Peñagaricano, F.; Souza, A.H.; Carvalho, P.D.; Driver, A.M.; Gambra, R.; Kropp, J.; Hackbart, K.S.; Luchini, D.; Shaver, R.D.; Wiltbank, M.C.; et al. Effect of maternal methionine supplementation on the transcriptome of bovine preimplantation embryos. PLoS ONE 2013, 8, e72302. [CrossRef] [PubMed]

97. Shojaei Saadi, H.A.; Gagné, D.; Fournier, É.; Baldoceda Baldeon, L.M.; Sirard, M.A.; Robert, C. Responses of bovine early embryos to S-adenosyl methionine supplementation in culture. Epigenomics 2016, 8, 1039-1060. [CrossRef]

98. Cooney, C.A.; Dave, A.A.; Wolff, G.L. Maternal Methyl Supplements in Mice Affect Epigenetic Variation and DNA Methylation of Offspring. J. Nutr. 2002, 132, 2393S-2400S. [CrossRef]

99. Jones, P.L.; Jan Veenstra, G.C.; Wade, P.A.; Vermaak, D.; Kass, S.U.; Landsberger, N.; Strouboulis, J.; Wolffe, A.P. Methylated DNA and MeCP2 recruit histone deacetylase to repress transcription. Nat. Genet. 1998, 19, 187-191. [CrossRef]

100. Dolinoy, D.C. The agouti mouse model: An epigenetic biosensor for nutritional and environmental alterations on the fetal epigenome. Nutr. Rev. 2008, 66 (Suppl. 1), S7-S11. [CrossRef]

101. Duhl, D.M.; Vrieling, H.; Miller, K.A.; Wolff, G.L.; Barsh, G.S. Neomorphic agouti mutations in obese yellow mice. Nat. Genet. 1994, 8, 59-65. [CrossRef] [PubMed]

102. Waterland, R.A.; Jirtle, R.L. Transposable elements: Targets for early nutritional effects on epigenetic gene regulation. Mol. Cell. Biol. 2003, 23, 5293-5300. [CrossRef] [PubMed]

103. Jirtle, R.L.; Skinner, M.K. Environmental epigenomics and disease susceptibility. Nat. Rev. Genet. 2007, 8, 253-262. [CrossRef] [PubMed]

104. Weinstein-Fudim, L.; Ergaz, Z.; Szyf, M.; Ornoy, A. Prenatal S-Adenosine Methionine (SAMe) Induces Changes in Gene Expression in the Brain of Newborn Mice That Are Prevented by Co-Administration of Valproic Acid (VPA). Int. J. Mol. Sci. 2020, 21, 2834. [CrossRef] [PubMed]

105. Ornoy, A.; Becker, M.; Weinstein-Fudim, L.; Ergaz, Z. S-Adenosine Methionine (SAMe) and Valproic Acid (VPA) as Epigenetic Modulators: Special Emphasis on their Interactions Affecting Nervous Tissue during Pregnancy. Int. J. Mol. Sci. 2020, $21,3721$. [CrossRef] [PubMed]

106. Feder, Y.; Nesher, E.; Ogran, A.; Kreinin, A.; Malatynska, E.; Yadid, G.; Pinhasov, A. Selective breeding for dominant and submissive behavior in Sabra mice. J. Affect. Disord. 2010, 126, 214-222. [CrossRef] [PubMed]

107. Becker, M.; Pinhasov, A.; Ornoy, A. Animal Models of Depression: What Can They Teach Us about the Human Disease? Diagnostics 2021, 11, 123. [CrossRef]

108. Becker, M.; Abaev, K.; Pinhasov, A.; Ornoy, A. S-adenosyl methionine alleviates depression like behavior in a mouse model of social hierarchy. J. Behav. Brain Res. 2022, article under review.

109. Frezza, M.; Centini, G.; Cammareri, G.; Le Grazie, C.; Di Padova, C. S-adenosylmethionine for the treatment of intrahepatic cholestasis of pregnancy. Results of a controlled clinical trial. Hepato-Gastroenterol. 1990, 37 (Suppl. 2), 122-125.

110. Coltorti, M.; Bortolini, M.; Di Padova, C. A review of the studies on the clinical use of S-adenosylmethionine (SAMe) for the symptomatic treatment of intrahepatic cholestasis. Methods Find. Exp. Clin. Pharmacol. 1990, 12, 69-78.

111. Hardy, M.L.; Coulter, I.; Morton, S.C.; Favreau, J.; Venuturupalli, S.; Chiappelli, F.; Rossi, F.; Orshansky, G.; Jungvig, L.K.; Roth, E.A.; et al. S-adenosyl-L-methionine for treatment of depression, osteoarthritis, and liver disease. Evid. Rep./Technol. Assess. 2003, $64,1-3$

112. Cozens, D.D.; Barton, S.J.; Clark, R.; Gibson, W.A.; Hughes, E.W.; Masters, R.E.; Offer, J.M.; Perkin, C.J.; Stramentinoli, G. Reproductive toxicity studies of ademetionine. Arzneim. -Forsch. 1988, 38, 1625-1629.

113. Zeisel, S.H.; Blusztajn, J.K. Choline and human nutrition. Annu. Rev. Nutr. 1994, 14, 269-296. [CrossRef]

114. Zeisel, S.H.; Klatt, K.C.; Caudill, M.A. Choline. Adv. Nutr. 2018, 9, 58-60. [CrossRef]

115. Caudill, M.A. Pre- and postnatal health: Evidence of increased choline needs. J. Am. Diet. Assoc. 2010, 110, 1198-1206. [CrossRef] [PubMed]

116. Cohen, E.L.; Wurtman, R.J. Brain acetylcholine: Control by dietary choline. Science 1976, 191, 561-562. [CrossRef]

117. Abreu-Villaca, Y.; Filgueiras, C.C.; Manhaes, A.C. Developmental aspects of the cholinergic system. Behav. Brain Res. 2011, 221, 367-378. [CrossRef] 
118. Zeisel, S.H.; Niculescu, M.D. Perinatal choline influences brain structure and function. Nutr. Rev. 2006, 64, 197-203. [CrossRef]

119. Hoffmann, L.; Brauers, G.; Gehrmann, T.; Häussinger, D.; Mayatepek, E.; Schliess, F.; Schwahn, B.C. Osmotic regulation of hepatic betaine metabolism. Am. J. Physiology. Gastrointest. Liver Physiol. 2013, 304, G835-G846. [CrossRef]

120. Traiffort, E.; O'Regan, S.; Ruat, M. The choline transporter-like family SLC44: Properties and roles in human diseases. Mol. Asp. Med. 2013, 34, 646-654. [CrossRef]

121. Lu, S.C.; Alvarez, L.; Huang, Z.-Z.; Chen, L.; An, W.; Corrales, F.J.; Avila, M.A.; Kanel, G.; Mato, J.M. Methionine adenosyltransferase $1 \mathrm{~A}$ knockout mice are predisposed to liver injury and exhibit increased expression of genes involved in proliferation. Proc. Natl. Acad. Sci. USA 2001, 98, 5560. [CrossRef] [PubMed]

122. Albright, C.D.; Tsai, A.Y.; Friedrich, C.B.; Mar, M.H.; Zeisel, S.H. Choline availability alters embryonic development of the hippocampus and septum in the rat. Brain Res. Dev. Brain Res. 1999, 113, 13-20. [CrossRef]

123. Albright, C.D.; Mar, M.H.; Friedrich, C.B.; Brown, E.C.; Zeisel, S.H. Maternal choline availability alters the localization of p15Ink4B and p27Kip1 cyclin-dependent kinase inhibitors in the developing fetal rat brain hippocampus. Dev. Neurosci. 2001, 23, 100-106. [CrossRef] [PubMed]

124. Niculescu, M.D.; Craciunescu, C.N.; Zeisel, S.H. Dietary choline deficiency alters global and gene-specific DNA methylation in the developing hippocampus of mouse fetal brains. FASEB J. 2006, 20, 43-49. [CrossRef] [PubMed]

125. Kwan, S.T.C.; King, J.H.; Grenier, J.K.; Yan, J.; Jiang, X.; Roberson, M.S.; Caudill, M.A. Maternal Choline Supplementation during Normal Murine Pregnancy Alters the Placental Epigenome: Results of an Exploratory Study. Nutrients 2018, 10, 417. [CrossRef] [PubMed]

126. Kwan, S.T.C.; King, J.H.; Yan, J.; Jiang, X.; Wei, E.; Fomin, V.G.; Roberson, M.S.; Caudill, M.A. Maternal choline supplementation during murine pregnancy modulates placental markers of inflammation, apoptosis and vascularization in a fetal sex-dependent manner. Placenta 2017, 53, 57-65. [CrossRef] [PubMed]

127. Cheng, R.K.; MacDonald, C.J.; Williams, C.L.; Meck, W.H. Prenatal choline supplementation alters the timing, emotion, and memory performance (TEMP) of adult male and female rats as indexed by differential reinforcement of low-rate schedule behavior. Learn Mem. 2008, 15, 153-162. [CrossRef]

128. Meck, W.H.; Williams, C.L. Choline supplementation during prenatal development reduces proactive interference in spatial memory. Brain Res. Dev. Brain Res. 1999, 118, 51-59. [CrossRef]

129. Trujillo-Gonzalez, I.; Friday, W.B.; Munson, C.A.; Bachleda, A.; Weiss, E.R.; Alam, N.M.; Sha, W.; Zeisel, S.H.; Surzenko, N. Low availability of choline in utero disrupts development and function of the retina. FASEB J. 2019, 33, 9194-9209. [CrossRef]

130. May, P.A.; Chambers, C.D.; Kalberg, W.O.; Zellner, J.; Feldman, H.; Buckley, D.; Kopald, D.; Hasken, J.M.; Xu, R.; HonerkampSmith, G.; et al. Prevalence of Fetal Alcohol Spectrum Disorders in 4 US Communities. JAMA 2018, 319, 474-482. [CrossRef]

131. Wozniak, J.R.; Riley, E.P.; Charness, M.E. Clinical presentation, diagnosis, and management of fetal alcohol spectrum disorder. Lancet Neurol. 2019, 18, 760-770. [CrossRef]

132. Portales-Casamar, E.; Lussier, A.A.; Jones, M.J.; MacIsaac, J.L.; Edgar, R.D.; Mah, S.M.; Barhdadi, A.; Provost, S.; LemieuxPerreault, L.P.; Cynader, M.S.; et al. DNA methylation signature of human fetal alcohol spectrum disorder. Epigenetics Chromatin 2016, 9, 25. [CrossRef]

133. Steane, S.E.; Fielding, A.M.; Kent, N.L.; Andersen, I.; Browne, D.J.; Tejo, E.N.; Gardebjer, E.M.; Kalisch-Smith, J.I.; Sullivan, M.A.; Moritz, K.M.; et al. Maternal choline supplementation in a rat model of periconceptional alcohol exposure: Impacts on the fetus and placenta. Alcohol Clin. Exp. Res. 2021, 45, 2130-2146. [CrossRef] [PubMed]

134. Sawant, O.B.; Birch, S.M.; Goodlett, C.R.; Cudd, T.A.; Washburn, S.E. Maternal choline supplementation mitigates alcohol-induced fetal cranio-facial abnormalities detected using an ultrasonographic examination in a sheep model. Alcohol 2019, 81, 31-38. [CrossRef] [PubMed]

135. Jacobson, S.W.; Carter, R.C.; Molteno, C.D.; Stanton, M.E.; Herbert, J.S.; Lindinger, N.M.; Lewis, C.E.; Dodge, N.C.; Hoyme, H.E.; Zeisel, S.H.; et al. Efficacy of Maternal Choline Supplementation During Pregnancy in Mitigating Adverse Effects of Prenatal Alcohol Exposure on Growth and Cognitive Function: A Randomized, Double-Blind, Placebo-Controlled Clinical Trial. Alcohol Clin. Exp. Res. 2018, 42, 1327-1341. [CrossRef] [PubMed]

136. Warton, F.L.; Molteno, C.D.; Warton, C.M.R.; Wintermark, P.; Lindinger, N.M.; Dodge, N.C.; Zollei, L.; van der Kouwe, A.J.W.; Carter, R.C.; Jacobson, J.L.; et al. Maternal choline supplementation mitigates alcohol exposure effects on neonatal brain volumes. Alcohol Clin. Exp. Res. 2021, 45, 1762-1774. [CrossRef] [PubMed]

137. Kable, J.A.; Coles, C.D.; Keen, C.L.; Uriu-Adams, J.Y.; Jones, K.L.; Yevtushok, L.; Kulikovsky, Y.; Wertelecki, W.; Pedersen, T.L.; Chambers, C.D.; et al. The impact of micronutrient supplementation in alcohol-exposed pregnancies on information processing skills in Ukrainian infants. Alcohol 2015, 49, 647-656. [CrossRef]

138. Ross, R.G.; Hunter, S.K.; McCarthy, L.; Beuler, J.; Hutchison, A.K.; Wagner, B.D.; Leonard, S.; Stevens, K.E.; Freedman, R. Perinatal choline effects on neonatal pathophysiology related to later schizophrenia risk. Am. J. Psychiatry 2013, 170, 290-298. [CrossRef]

139. Boeke, C.E.; Gillman, M.W.; Hughes, M.D.; Rifas-Shiman, S.L.; Villamor, E.; Oken, E. Choline intake during pregnancy and child cognition at age 7 years. Am. J. Epidemiol. 2013, 177, 1338-1347. [CrossRef]

140. Caudill, M.A.; Strupp, B.J.; Muscalu, L.; Nevins, J.E.H.; Canfield, R.L. Maternal choline supplementation during the third trimester of pregnancy improves infant information processing speed: A randomized, double-blind, controlled feeding study. FASEB J. 2018, 32, 2172-2180. [CrossRef] 
141. Freedman, R.; Hunter, S.K.; Law, A.J.; Wagner, B.D.; D’Alessandro, A.; Christians, U.; Noonan, K.; Wyrwa, A.; Hoffman, M.C. Higher Gestational Choline Levels in Maternal Infection Are Protective for Infant Brain Development. J. Pediatrics 2019, 208, 198-206. [CrossRef] [PubMed]

142. Cheatham, C.L.; Goldman, B.D.; Fischer, L.M.; da Costa, K.A.; Reznick, J.S.; Zeisel, S.H. Phosphatidylcholine supplementation in pregnant women consuming moderate-choline diets does not enhance infant cognitive function: A randomized, double-blind, placebo-controlled trial. Am. J. Clin. Nutr. 2012, 96, 1465-1472. [CrossRef] [PubMed]

143. Wozniak, J.R.; Fuglestad, A.J.; Eckerle, J.K.; Fink, B.A.; Hoecker, H.L.; Boys, C.J.; Radke, J.P.; Kroupina, M.G.; Miller, N.C.; Brearley, A.M.; et al. Choline supplementation in children with fetal alcohol spectrum disorders: A randomized, double-blind, placebo-controlled trial. Am. J. Clin. Nutr. 2015, 102, 1113-1125. [CrossRef]

144. Sarkar, D.K.; Gangisetty, O.; Wozniak, J.R.; Eckerle, J.K.; Georgieff, M.K.; Foroud, T.M.; Wetherill, L.; Wertelecki, W.; Chambers, C.D.; Riley, E.; et al. Persistent Changes in Stress-Regulatory Genes in Pregnant Women or Children Exposed Prenatally to Alcohol. Alcohol Clin. Exp. Res. 2019, 43, 1887-1897. [CrossRef] [PubMed]

145. Nguyen, T.T.; Risbud, R.D.; Mattson, S.N.; Chambers, C.D.; Thomas, J.D. Randomized, double-blind, placebo-controlled clinical trial of choline supplementation in school-aged children with fetal alcohol spectrum disorders. Am. J. Clin. Nutr. 2016, 104, 1683-1692. [CrossRef] 